\title{
Estimation of a Minimum Allowable Structural Strength Based on Uncertainty in Material Test Data
} \author{
Gaithersburg, MD 20899, USA \\ ${ }^{2}$ MPACT Corp., \\ Oak Park, CA 91377, USA \\ ${ }^{3}$ Freiman Consulting, \\ Potomac, MD 20854, USA \\ Jeffrey.fong@ nist.gov \\ Alan.heckert@nist.gov \\ James.filliben@nist.gov \\ pedrovmarcal@gmail.com \\ steve.freiman@ comcast.net
}

Jeffrey T. Fong ${ }^{1}$, N. Alan Heckert ${ }^{1}$, James J. Filliben ${ }^{1}$, Pedro V. Marcal ${ }^{2}$, and Stephen W. Freiman ${ }^{3}$

${ }^{1}$ National Institute of Standards and Technology,

Three types of uncertainties exist in the estimation of the minimum fracture strength of a full-scale component or structure size. The first, to be called the "model selection uncertainty," is in selecting a statistical distribution that best fits the laboratory test data. The second, to be called the "laboratory-scale strength uncertainty," is in estimating model parameters of a specific distribution from which the minimum failure strength of a material at a certain confidence level is estimated using the laboratory test data. To extrapolate the laboratory-scale strength prediction to that of a full-scale component, a third uncertainty exists that can be called the "full-scale strength uncertainty." In this paper, we develop a three-step approach to estimating the minimum strength of a full-scale component using two metrics: One metric is based on six goodness-of-fit and parameter-estimation-method criteria, and the second metric is based on the uncertainty quantification of the so-called A-basis design allowable ( $99 \%$ coverage at $95 \%$ level of confidence) of the full-scale component. The three steps of our approach are: (1) Find the "best" model for the sample data from a list of five candidates, namely, normal, two-parameter Weibull, three-parameter Weibull, two-parameter lognormal, and three-parameter lognormal. (2) For each model, estimate (2a) the parameters of that model with uncertainty using the sample data, and (2b) the minimum strength at the laboratory scale at $95 \%$ level of confidence. (3) Introduce the concept of "coverage" and estimate the fullscale allowable minimum strength of the component at $95 \%$ level of confidence for two types of coverages commonly used in the aerospace industry, namely, $99 \%$ (A-basis for critical parts) and $90 \%$ (B-basis for less critical parts). This uncertainty-based approach is novel in all three steps: In step-1 we use a composite goodness-of-fit metric to rank and select the "best" distribution, in step-2 we introduce uncertainty quantification in estimating the parameters of each distribution, and in step-3 we introduce the concept of an uncertainty metric based on the estimates of the upper and lower tolerance limits of the so-called A-basis design allowable minimum strength. To illustrate the applicability of this uncertainty-based approach to a diverse group of data, we present results of our analysis for six sets of laboratory failure strength data from four engineering materials. A discussion of the significance and limitations of this approach and some concluding remarks are included.

Key words: aluminum oxide; Anderson-Darling criterion; ASTM C1239-07; borosilicate crown BK-7 glass; chi-square criterion; DATAPLOT; failure strength test; goodness-of-fit; high-strength steels; Kolmogorov-Smirnov criterion; lognormal; maximum likelihood method; model selection; normal; probability plot correlation coefficient; probability plot correlation coefficient criterion; silicon nitride; statistical data analysis; structural reliability; uncertainty quantification; Weibull distribution.

Accepted: November 4, 2021

Published: December 7, 2021

https://doi.org/10.6028/jres.126.036 


\section{Introduction}

One of the most difficult questions in structural engineering design and failure analysis is how to best fit a set of fracture, yield, or ultimate strength test data. In the standard practice for advanced ceramic materials recommended by ASTM International [1], the two-parameter (2p) Weibull distribution with a zero-location parameter was used (see, e.g., Fig. 1). The choice of the $2 p$ Weibull, rather than other models such as the three-parameter ( $3 p$ ) Weibull, or $2 p$ or $3 p$ lognormal, etc., may conceivably be attributed to a lack of (a) efficient computational codes for parameter estimation for alternative distributions in the literature, and (b) easy-to-use criteria for choosing the "best" distribution among competing and equally reasonable one.

While recognizing that the zero-location feature of a $2 p$ Weibull model might be acceptable for modeling the life of a product $[2,3,4]$, one cannot help but observe that a $2 p$ Weibull is physically unrealistic for modeling the minimum strength of an engineering material, because it assumes that among all possible samples of an engineering material, one will likely fail a simple tensile strength test near the zero load. It is also unduly conservative when recommended as the so-called A-basis (99\% coverage) for critical and B-basis (90\% coverage) for less-critical structural design allowable in aerospace industry [5].

To illustrate the need for a re-examination of the basis for choosing the "best" model of a set of tensile strength data, we applied the ASTM recommended practice C1239-07 [1] to a set of 31 ring-on-ring test data for an aircraft window material, borosilicate crown BK-7 glass (see Appendix A, Data Set No. 1, which is based on Fuller et al. [6]). In Figs. 1 and 2, we present the 2p Weibull probability plot and the histogram and probability density function, respectively, of the 31 data point set according to ASTM 123907. In this exercise, we used the maximum likelihood (ML) method [7, 8] in a statistical analysis code (written in DATAPLOT [9]) to estimate the parameters of a 2p Weibull distribution. In Fig. 3, we used the same code to make a quantile-quantile (QQ) plot of the same set of data $v s$. the predicted values based on a 2 p Weibull. In both Figs. 1 and 3, we observe that near the lower values of the 31 data point set, the fit is not so good. On the other hand, when we used the same code to estimate the parameters of a $3 p$ Weibull, the fit is remarkably good, as shown in Figs. 4 and 5.

To improve the 2p Weibull methodology recommended in the ASTM standard practice C1239-07 [1] for reporting strength data of ceramic materials, we developed a set of new tools not only for a set of five distributions (normal, 2p Weibull, 3p Weibull, 2p lognormal, 3p lognormal), but also for a broader class of materials that includes ceramics, metal alloys and composites. Our approach consists of three steps (see Sec. 2, 3, and 4, respectively):

Step 1. Model Selection. Find the "best" model for the sample data from a list of five candidates, namely, normal, 2p Weibull, 3p Weibull, 2p lognormal, and 3p lognormal. Analysis results for glass data are given in Sec. 2, Table 1.

Step 2. Laboratory-Scale Statistical Analysis. Estimate with uncertainty quantification for each model the parameters of that model using the sample data and the lower and upper bounds of the minimum strength at the laboratory scale for a $95 \%$ level of confidence. Analysis results for glass data are given in Sec. 3, Table 2 . 
Journal of Research of the National Institute of Standards and Technology

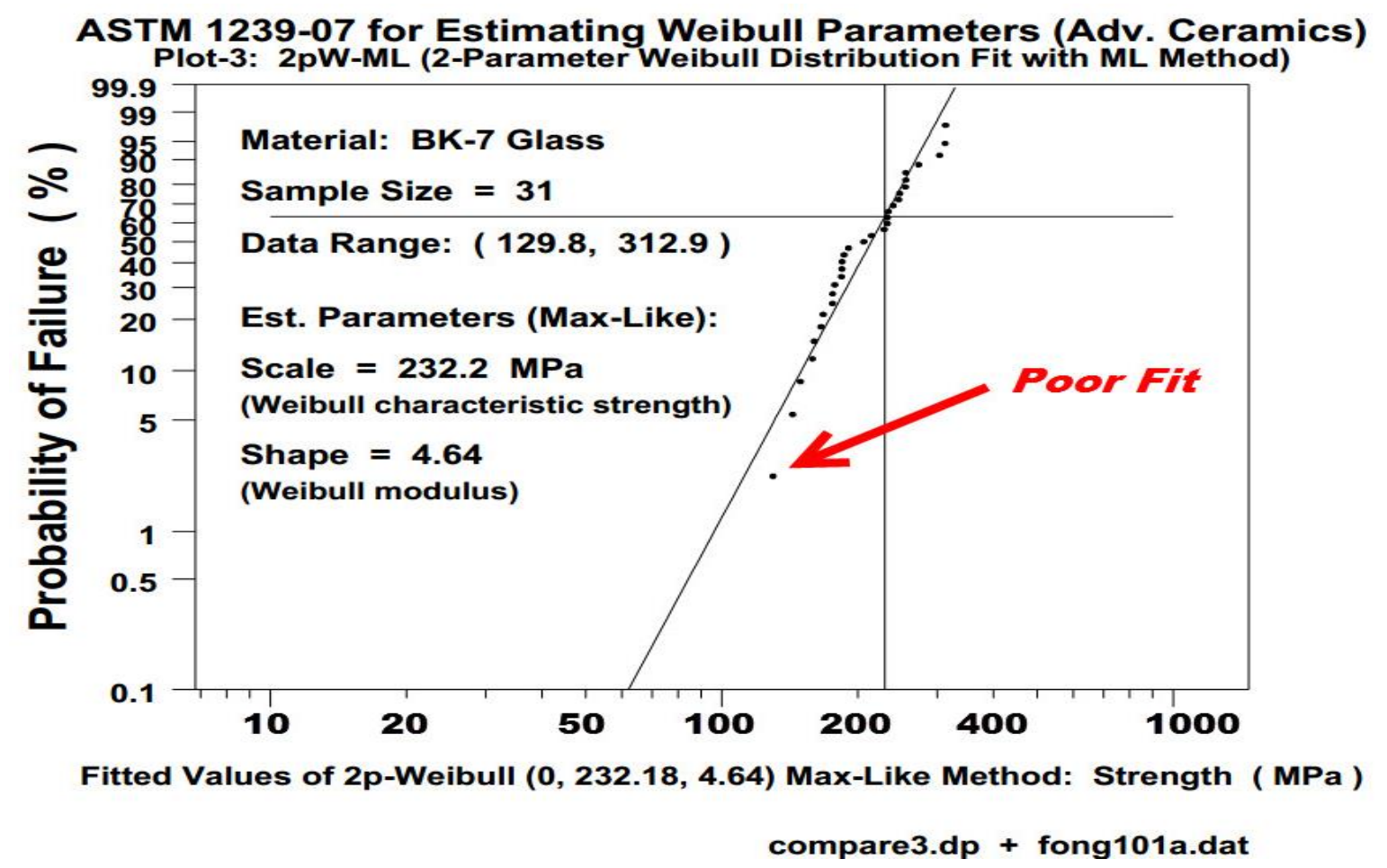

Fig. 1. A two-parameter Weibull plot of a set of 31 biaxial test data for the ultimate tensile strength of a BK-7 glass [6].

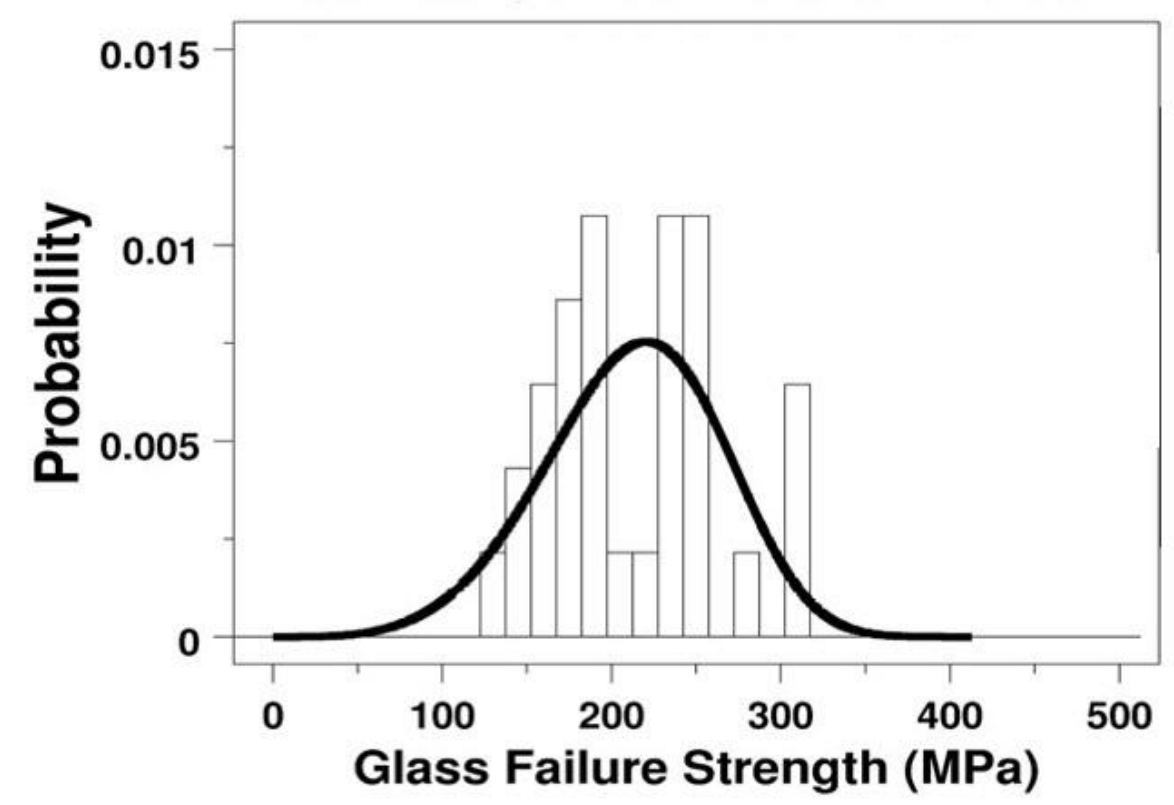

Fig. 2. Histogram and $2 p$ Weibull probability density function of a set of 31 biaxial test data for the ultimate tensile strength of a BK-7 glass [6]. Using the maximum likelihood method of parameter estimation, we found the scale parameter is $232.2 \mathrm{MPa}$, and the shape is 4.64 (for $n=31$ ). 
Journal of Research of the National Institute of Standards and Technology

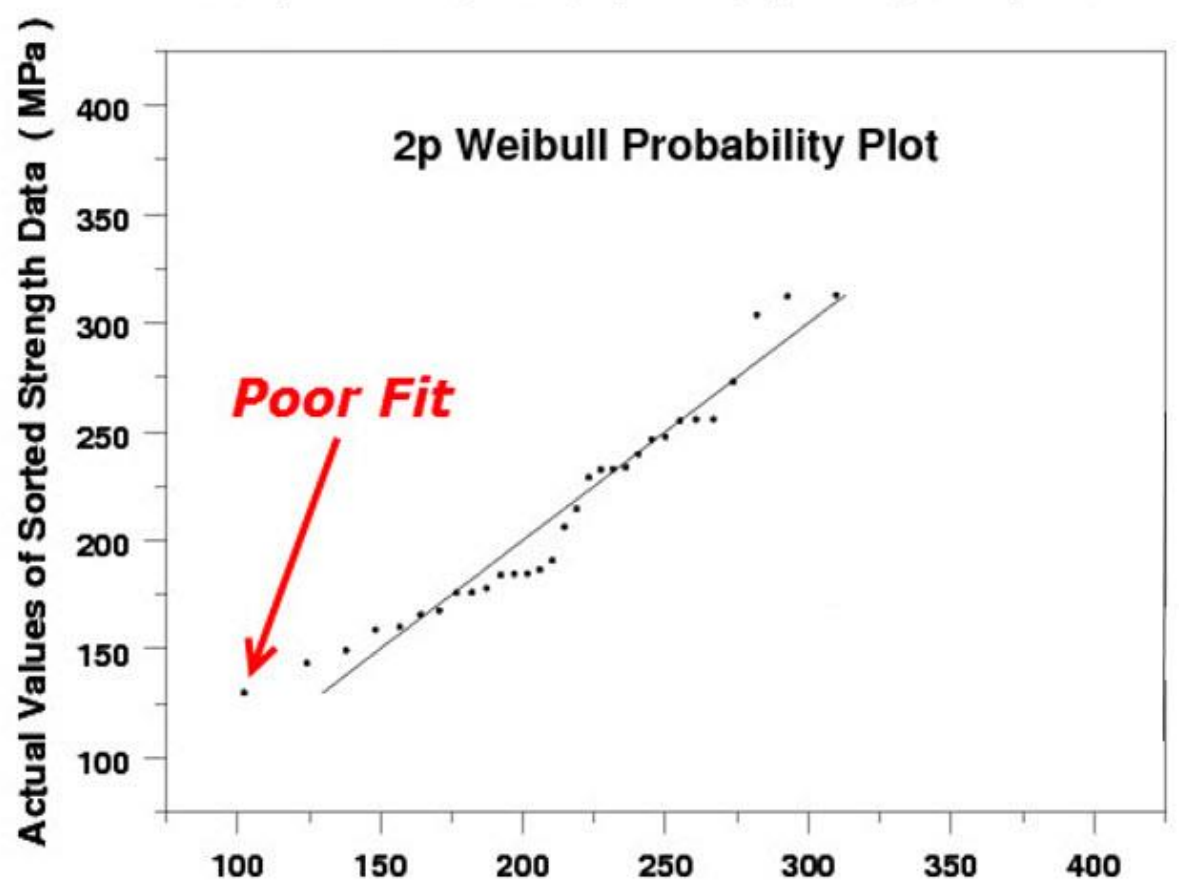

Fitted Values of 2p-Weibull (0. 232.18. 4.64) Max-Like Method: Strength ( MPa )

Fig. 3. BK-7 glass: A $2 p$ Weibull probability plot of the glass strength data $v s$. predicted values.

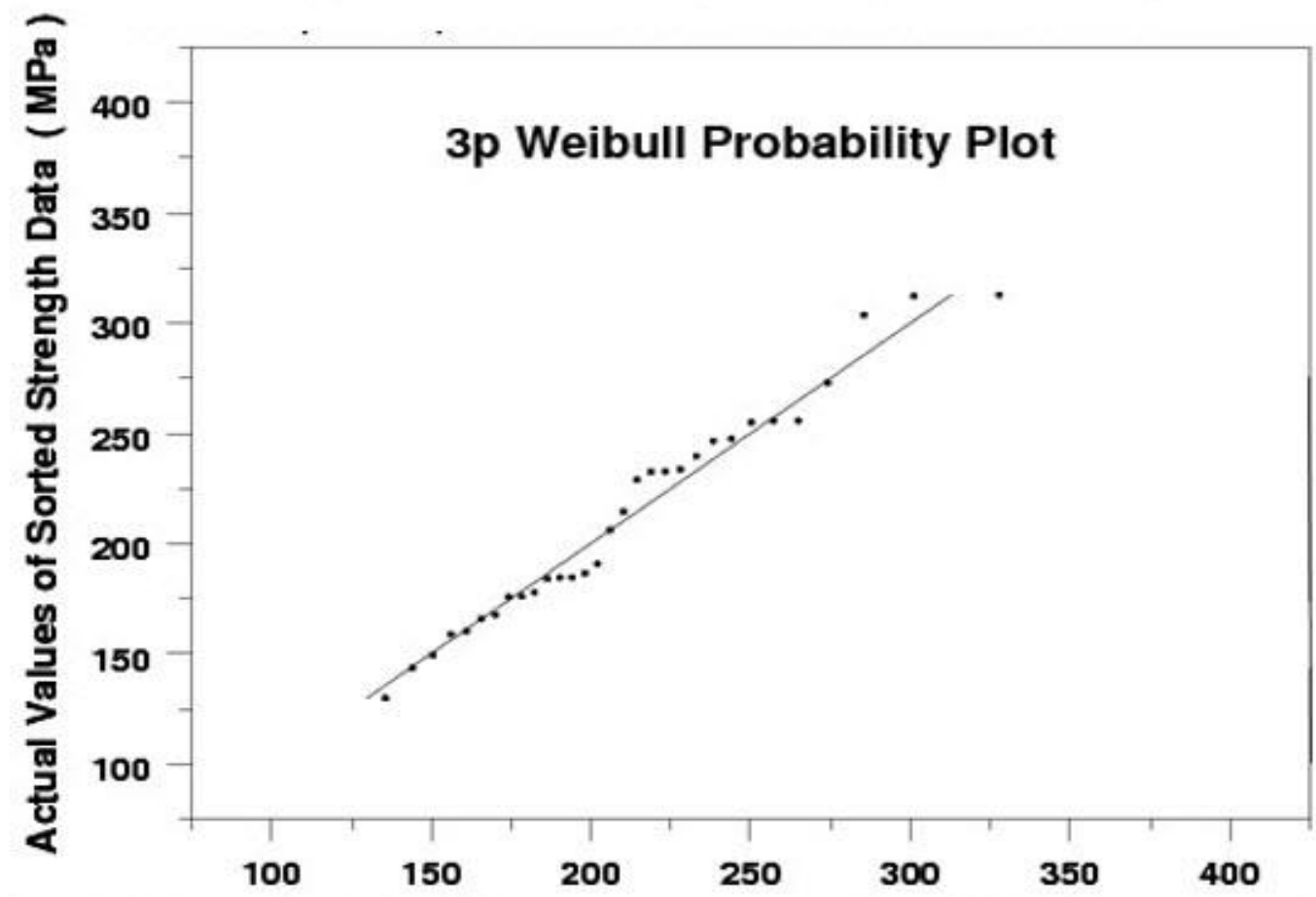

Fitted Values of 3p-Weibull $(121.65,102.29,1.91)$ Max-Like Method: Strength (MPa )

Fig. 4. BK-7 glass: A 3p Weibull probability plot of the glass strength data $v s$. predicted values. 


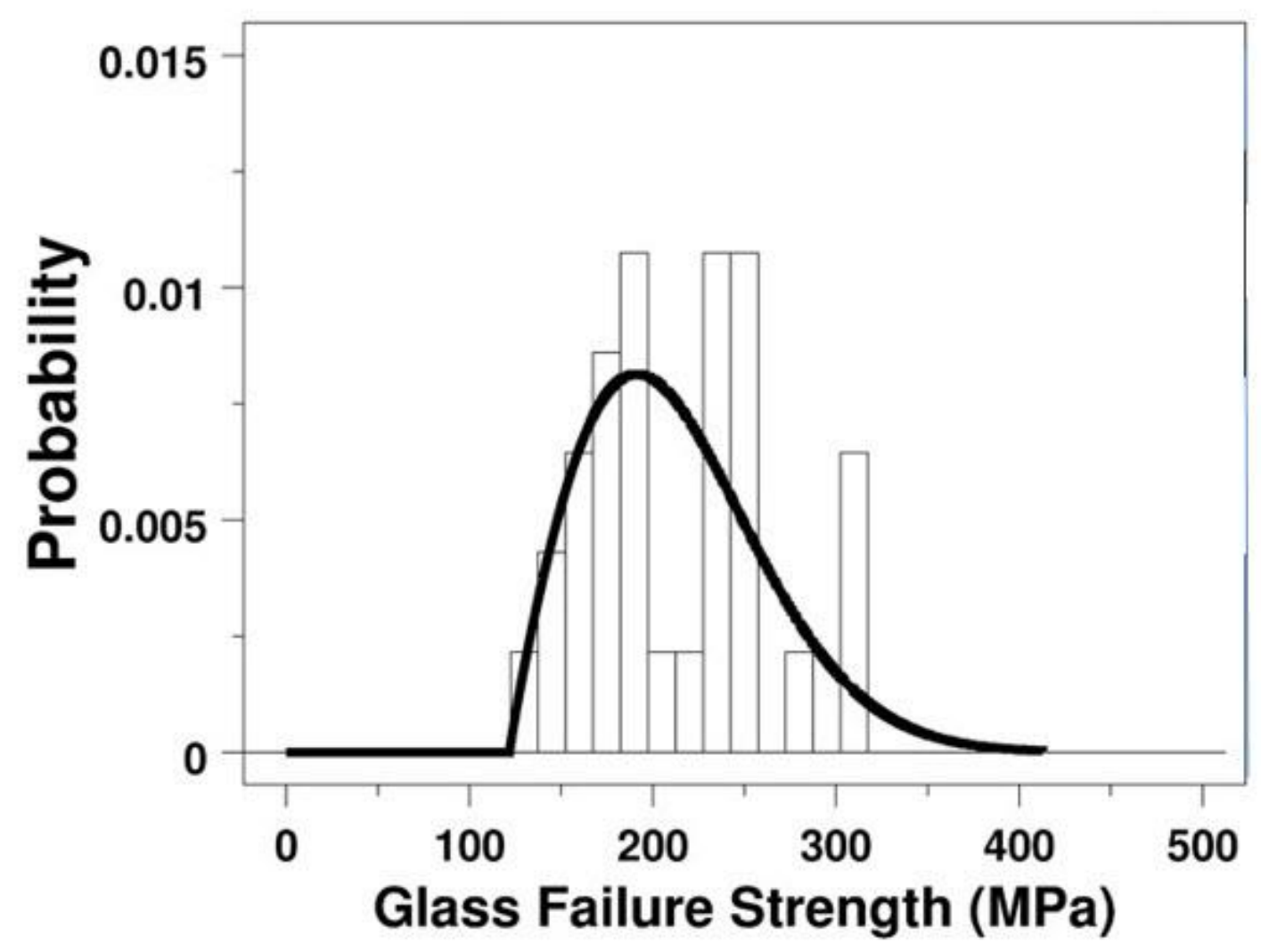

Fig. 5. BK-7 glass: Histogram and 3p Weibull probability density function for the same strength data. Using the ML method of parameter estimation, we found the location parameter is $121.7 \mathrm{MPa}$, the scale is $102.3 \mathrm{MPa}$, and the shape is 1.91 (for $n=31$ ).

Step 3. Full-Scale Statistical Analysis. We introduce in Sec. 4 the concept of "coverage" and the classical theory of tolerance limits to estimate the minimum allowable strength, also with uncertainty quantification, of a full-scale structure at $95 \%$ confidence level and two specific sizes of coverage, namely $99 \%$ (also known as the A-basis) and $90 \%$ (known as the B-basis).

In Sec. 5, we show the results of applying this new approach to six data sets (see Appendix A) from four engineering materials. The significance of our approach and some concluding remarks are given in Sec. 6 and Sec. 7, respectively. In addition to Sec. 3, Table 2 (results for Data Set No. 1), we attach in Appendices $\mathrm{C}$ through $\mathrm{G}$ the complete numerical results of the application of our approach for Data Set Nos. 2 through 6, respectively.

\section{Model Selection (Step 1 of 3 )}

We began the development of our new approach by considering five candidate models and selecting the "best" over two parameter-estimation (PE) methods and four goodness-of-fit (GoF) criteria. The five candidate models were:

(1) Model 1: normal (N).

(2) Model 2: two-parameter Weibull $(2 p \mathrm{~W})$.

(3) Model 3: three-para. Weibull ( $3 p \mathrm{~W})$.

(4) Model 4: two-para. lognormal $(2 p \mathrm{LN})$.

(5) Model 5: three-para. lognormal $(3 p \mathrm{LN})$.

The two-parameter estimation (PE) methods were: 
(1) PE Method No. 1: Maximum likelihood (ML) method (see, e.g., Bury [10, pp. 161-168], Aldrich [7], and Anderson [8]).

(2) PE Method No. 2: Probability plot correlation coefficients (PPCC) method (see, Filliben [11, 12], Looney and Gulledge Jr. [13], and Vogel [14]).

The four GoF criteria are:

(1) GoF Criterion 1. Anderson Darling (AD) test (see Anderson and Darling [15, 16]).

(2) GoF Criterion 2. Kolmogorov-Smirnov (KS) test (see, e.g., Bury [10, pp. 204-208]).

(3) GoF Criterion 3. Chi square (CS) test (see, e.g., Bury [10, pp. 196-203]).

(4) GoF Criterion 4. Probability plot correlation coefficient (PC) test (see, e.g., Filliben [11, 12], Looney and Gulledge Jr. [13], and Vogel [14]).

To compute the GoF statistics for each model, we adopted the following six GoF-PE scenarios:

(1) GoF-PE Scenario 1 (CS-1): GoF Criterion 3 (CS) with PE Method No. 1 (ML).

(2) GoF-PE Scenario 2 (AD-1): GoF Criterion 1 (AD) with PE Method No. 1 (ML).

(3) GoF-PE Scenario 3 (KS-1): GoF Criterion 2 (KS) with PE Method No. 1 (ML).

(4) GoF-PE Scenario 4 (AD-2): GoF Criterion 1 (AD) with PE Method No. 2 (PC).

(5) GoF-PE Scenario 5 (KS-2): GoF Criterion 2 (KS) with PE Method No. 2 (PC).

(6) GoF-PE Scenario 6 (PC-2): GoF Criterion 4 (PC) with PE Method No. 2 (PC).

To test our methodology, we obtained from the literature a total of six data sets (see Appendix A) for four materials, namely, BK-7 glass (Data Set No. 1), silicon nitrate (Data Set No. 2 and Data Set No. 3 for two different test methods), aluminum oxide (Data Set No. 4), and a high-strength steel (Data Set- No. 5 and Data Set No. 6 for two different temperature environments). Based on formulas in the statistics literature [17-20], we wrote an analysis code in DATAPLOT to capture the GoF statistics for the six GoFPE scenarios of all five models for each of the six ultimate strength data sets as listed in Appendix A. Results of the analysis for all five models with their raw GoF statistics for each of the six data sets are given in Appendix B.

An examination of the raw GoF statistics for each data set in Appendix B showed a qualitative difference between those of the first five GoF-PE scenarios (CS-1, AD-1, KS-1, AD-2 and KS-2) and the sixth scenario (PC-2): namely, the former interprets a smaller statistic to be a better fit, whereas the latter demands that a larger statistic is better. This requires us to develop two sets of normalization formulas as follows:

(1) For each of the five scenarios, CS-1, AD-1, KS-1, AD-2, and KS-2, let $x_{i},(i=1, \ldots, 5)$, be the GoF statistics of the five candidate models being considered for selection, and let $x_{\max }$ and $x_{\min }$ be the maximum and minimum of the five statistics, $x_{i},(i=1, \ldots, 5)$, respectively. The normalized statistic of $x_{i},(i=1, \ldots$, $5)$, to be denoted by $N x_{i},(i=1, \ldots, 5)$, is defined as follows:

$$
N x_{i}=\left(x_{i}-x_{\max }\right) /\left(x_{\min }-x_{\max }\right), \quad(i=1, \ldots, 5) .
$$

(2) For the sixth scenario, PC-2, let $y_{i},(i=1, \ldots, 5)$, be the GoF statistics of the five candidate models being considered for selection, and let $y_{\max }$ and $y_{\min }$ be the maximum and minimum of the five statistics, $y_{i}$, $(i=1, \ldots, 5)$, respectively. The normalized statistic of $y_{i},(i=1, \ldots, 5)$, to be denoted by $N y_{i},(i=1, \ldots, 5)$, is defined as follows:

$$
N y_{i}=\left(y_{i}-y_{\min }\right) /\left(y_{\max }-y_{\min }\right), \quad(i=1, \ldots, 5) .
$$

Using the average of the normalized GoF statistics as a metric for ranking (with 1 being good, 0 being poor) as shown in the second row from the bottom of Table 1 , we observe that the $3 \mathrm{pW}$ model (metric $1=$ 1.00) ranks first among all five candidate models for Data Set No. 1 (BK-7 glass). 


\section{Journal of Research of the National Institute of Standards and Technology}

Table 1. Data Set No. 1: BK-7 glass-Goodness-of-fit statistics for five candidate models.

\begin{tabular}{|c|c|c|c|c|c|c|c|}
\hline No. & $\begin{array}{l}\text { GoF- } \\
\text { PE } \\
\text { Combo }\end{array}$ & $\begin{array}{l}\text { Goodness-of-Fit (GoF) and } \\
\text { Parameter Estimation (PE) } \\
\text { Method Statistical Analysis } \\
\text { Scenario Description }\end{array}$ & $\begin{array}{l}\text { Model } 1 \\
\text { Normal }\end{array}$ & $\begin{array}{l}\text { Model } 2 \\
\text { Two- } \\
\text { parameter } \\
\text { Weibull }\end{array}$ & $\begin{array}{l}\text { Model } 3 \\
\text { Three- } \\
\text { parameter } \\
\text { Weibull }\end{array}$ & $\begin{array}{l}\text { Model } 4 \\
\text { Two- } \\
\text { parameter } \\
\text { lognormal }\end{array}$ & $\begin{array}{l}\text { Model } 5 \\
\text { Three- } \\
\text { parameter } \\
\text { lognormal }\end{array}$ \\
\hline 1 & CS-1 & $\begin{array}{r}\text { Chi square (CS) criterion } \\
+\mathrm{ML} \text { method (PE-1) } \\
\text { gives GoF statistics }= \\
\text { (Note: Small is good.) } \\
\\
\text { Normalized CS-1 statistics } \\
\text { between } 0 \text { and } 1 \text { (best) }=\end{array}$ & 13.72 & 13.70 & 10.61 & 11.65 & 11.91 \\
\hline 2 & AD-1 & $\begin{array}{r}\text { Anderson-Darling (AD) } \\
+ \text { ML method (PE-1) } \\
\text { gives GoF statistics = } \\
\text { (Note: Small is good.) } \\
\text { Normalized AD-1 statistics } \\
\text { between } 0 \text { and } 1 \text { (best) }=\end{array}$ & 0.532 & 0.597 & 0.338 & 0.389 & 0.398 \\
\hline 3 & KS-1 & $\begin{array}{r}\text { Kolmogorov-Smirnov (KS) } \\
+ \text { ML method (PE-1) } \\
\text { gives GoF statistics = } \\
\text { (Note: Small is good.) } \\
\\
\text { Normalized KS-1 statistics } \\
\text { between } 0 \text { and } 1 \text { (best) }=\end{array}$ & 0.151 & 0.153 & 0.117 & 0.122 & 0.129 \\
\hline 4 & AD-2 & $\begin{array}{r}\text { Anderson-Darling }(\mathrm{AD})+ \\
\text { probability plot correlation } \\
\text { coefficient }(\mathrm{PC}) \text { method } \\
\text { (PE-2) gives GoF statistics = } \\
\text { (Note: Small is good.) } \\
\text { Normalized AD-2 statistics } \\
\text { between } 0 \text { and } 1 \text { (best) }=\end{array}$ & 0.513 & & 0.318 & & 0.374 \\
\hline 5 & KS-2 & $\begin{array}{r}\text { Kolmogorov-Smirnov }(\mathrm{KS})+ \\
\text { probability plot correlation } \\
\text { coefficient }(\mathrm{PC}) \text { method } \\
\text { (PE-2) gives GoF statistics = } \\
\text { (Note: Small is good.) } \\
\text { Normalized KS-2 statistics } \\
\text { between } 0 \text { and } 1 \text { (best) = }\end{array}$ & 0.149 & & 0.114 & & 0.124 \\
\hline 6 & PC-2 & $\begin{array}{r}\text { Probability plot correlation } \\
\text { coefficient (PC) criterion } \\
+ \text { PC method (PE-2) } \\
\text { gives GoF statistics = } \\
\text { (Note: Large is good.) } \\
\text { Normalized PC-2 statistics } \\
\text { between } 0 \text { and } 1 \text { (best) }=\end{array}$ & 0.980 & & 0.988 & & 0.986 \\
\hline & & $\begin{array}{l}\text { Column sum of all } \\
\text { normalized statistics }=\end{array}$ & 0.31 & 0.01 & 6.00 & 2.33 & 4.19 \\
\hline & & $\begin{array}{r}\text { Average of normalized GoF } \\
\text { statistic from } 0 \text { to } 1=\end{array}$ & 0.05 & $\begin{array}{r}0.00 \\
\text { (worst) }\end{array}$ & $\begin{array}{r}1.00 \\
\text { (best) }\end{array}$ & 0.78 & 0.60 \\
\hline & & $\begin{array}{c}\text { GoF ranking } \\
\text { (1 being best, and } \\
5 \text { being worst) }\end{array}$ & 4 & 5 & 1 & 2 & 3 \\
\hline
\end{tabular}




\section{Parameter Estimation and Minimum Strength at Laboratory Scale (Step 2 of 3)}

In the last section (Step 1: Model Selection), we applied a multiple PE-method-GoF scenario technique and an elementary two-step normalization algorithm to develop a composite GoF index as a "metric" for ranking the five candidate models according to which one "best" fits a given set of strength data. Having chosen the $3 \mathrm{pW}$ as the "best- fit" model, we wrote a second analysis code that gave not only the point estimates of the location, scale, and shape parameters of the $3 \mathrm{pW}$, but also their standard errors, upper and lower limits at various confidence intervals (which are useful in this step, step 2, to estimate the minimum strength at laboratory sample-size scale), the one-sided tolerance limits at $95 \%$ confidence level for 12 coverages varying from $90 \%$ to $99.99999999 \%$ (which are useful in the next step, step 3, that is designed to estimate the upper and lower limits of the minimum strength at full-scale component size).

In order to clarify the difference between the two estimates of the minimum strength, or the location parameter (for a $3 \mathrm{pW}$ model), one being at the laboratory sample-size scale, and the other being at the fullscale component size, we will address in this section only the second step (laboratory scale) of our methodology by using the first half of the analysis results (without coverages), that is, based on the second analysis code, "3pW_0.05x.dp." Figure 6 shows a plot of the results for Data Set No. 1 using the 3pW model to estimate the minimum strength and its uncertainty at laboratory scale. The complete results of our three-step analysis for all five models for Data Set No. 1 are tabulated in Table 2.

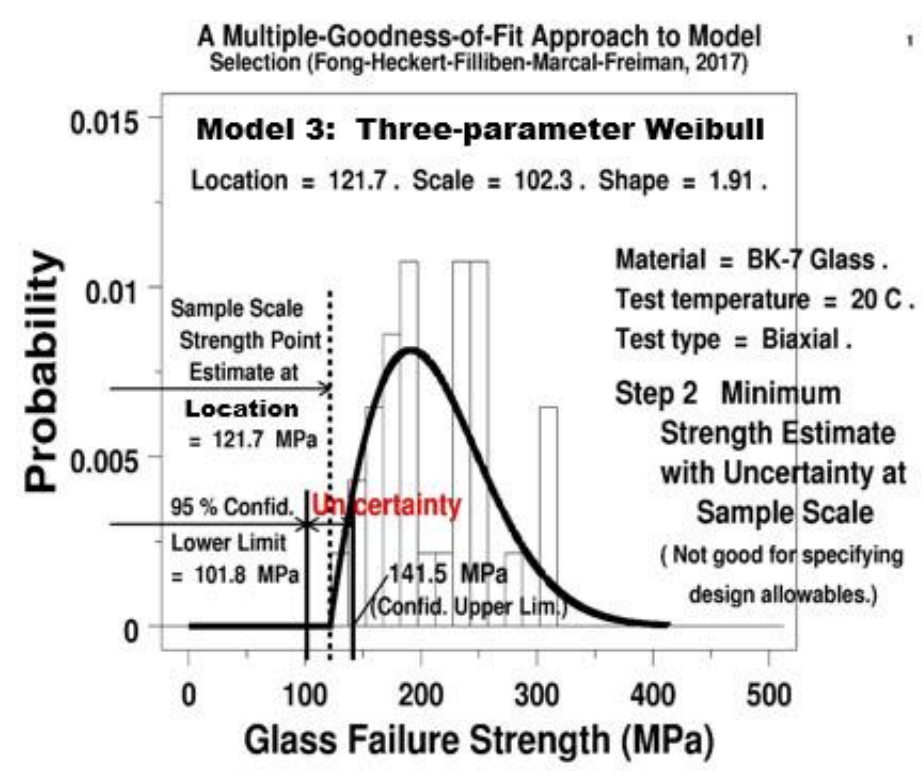

Fig. 6. BK-7 glass: Histogram and fitted $3 p$ Weibull probability density function for the same strength data with lower and upper $95 \%$ confidence limits for the location parameter at the sample scale. 
Table 2. Estimates of minimum strength at laboratory-scale and full-scale sizes for five candidate models based on Data Set No. 1 (BK-7 glass) at $20{ }^{\circ} \mathrm{C}$ (biaxial strength test).

\begin{tabular}{|c|c|c|c|c|c|}
\hline & $\begin{array}{l}\text { Model } 1 \\
\text { Normal }\end{array}$ & $\begin{array}{c}\text { Model 2 } \\
\text { 2p Weibull }\end{array}$ & $\begin{array}{c}\text { Model 3 } \\
\text { 3p Weibull }\end{array}$ & $\begin{array}{c}\text { Model } 4 \\
\text { 2p lognormal }\end{array}$ & $\begin{array}{c}\text { Model 5 } \\
\text { 3p lognormal }\end{array}$ \\
\hline \multicolumn{6}{|l|}{ Laboratory-Scale } \\
\hline $\begin{array}{l}\text { Composite normalized } \\
\text { GoF statistic (metric } 1 \text { ) } \\
\text { (Ranges from } 0 \text { to } 1 \text {, } \\
\text { worst to best.) }\end{array}$ & 0.05 & $\begin{array}{c}0 \\
\text { (worst) }\end{array}$ & $\begin{array}{c}1.0 \\
\text { (best) }\end{array}$ & 0.78 & 0.60 \\
\hline $\begin{array}{l}\text { Parameter } 1 \text { (Location) } \\
\text { Point estimate of location, } \\
\text { Standard deviation of location }\end{array}$ & 212.4 & None. & 121.7 & None. & 77.3 \\
\hline $\begin{array}{l}\text { One-sided } 95 \% \text { confidence } \\
\text { minimum strength at sample } \\
\text { scale = ( lower limit, } \\
\text { point estimate, } \\
\text { upper limit })\end{array}$ & $\begin{array}{l}\left(\begin{array}{l}95.6, \\
130.2, \\
153.0)\end{array}\right. \\
\end{array}$ & $\begin{array}{l}\text { (96.1, } \\
\begin{array}{l}122.3, \\
148.6)\end{array} \\
\end{array}$ & $\begin{array}{l}\text { (101.8, } \\
\quad 121.7 \\
141.5) \\
\end{array}$ & $\begin{array}{l}\text { (119.5, } \\
\quad \begin{array}{l}140.6, \\
156.5)\end{array} \\
\end{array}$ & $\begin{array}{l}(-85.0, \\
\quad 41.8, \\
\quad 169.0) \\
\end{array}$ \\
\hline $\begin{array}{l}\text { Parameter } 2 \text { (Scale) } \\
\text { Point estimate of scale, } \\
\text { Standard deviation of scale }\end{array}$ & 50.0 & 232.2 & 102.3 & 206.9 & 163.6 \\
\hline $\begin{array}{l}\text { Parameter } 3 \text { (Shape) } \\
\text { Point estimate of shape, } \\
\quad \text { Standard deviation of shape }\end{array}$ & None. & 0.65 & 0.45 & 0.03 & 0.15 \\
\hline \multicolumn{6}{|l|}{ Full-Scale Size } \\
\hline $\begin{array}{l}95 \% \text { confidence, } 99 \% \\
\text { coverage A-basis design } \\
\text { allowable (AbDA) } \\
\text { Uncertainty (metric } 2 \text { ) } \\
\text { (Note: Small is good.) }\end{array}$ & $\begin{array}{c}38 \% \\
\text { (worst) }\end{array}$ & $30 \%$ & $\begin{array}{l}11 \% \\
\text { (best) }\end{array}$ & $16 \%$ & $19 \%$ \\
\hline $\begin{array}{l}95 \% \text { confidence, } 99 \% \\
\text { coverage minimum strength at } \\
\text { full scale } \\
\text { ( lower tolerance limit } \\
\text { or A-basis of design, } \\
\text { mean estimate, } \\
\text { upper tolerance limit ) }\end{array}$ & $\begin{array}{l}\text { (51.7, } \\
\quad 96.1, \\
\quad 124.1)\end{array}$ & $\begin{array}{l}(60.0, \\
86.1, \\
\quad 112.5)\end{array}$ & $\begin{array}{l}(116.3, \\
130.9, \\
\quad 145.5)\end{array}$ & $\begin{array}{l}(97.2, \\
\quad \begin{array}{l}119.8, \\
136.6)\end{array}\end{array}$ & $\begin{array}{l}(101.3, \\
124.8, \\
148.4)\end{array}$ \\
\hline $\begin{array}{l}95 \% \text { confidence, } 90 \% \\
\text { coverage minimum strength at } \\
\text { full scale } \\
\text { ( lower tolerance limit } \\
\text { or B-basis of design, } \\
\text { mean estimate, } \\
\text { upper tolerance limit ) }\end{array}$ & $\begin{array}{l}\text { (118.6, } \\
\begin{array}{l}148.4, \\
168.8)\end{array}\end{array}$ & $\begin{array}{l}(117.8, \\
142.9, \\
\quad 168.0)\end{array}$ & $\begin{array}{l}(139.5, \\
153.2 \\
\quad 166.9)\end{array}$ & $\begin{array}{l}\text { (133.1, } \\
\begin{array}{l}\text { 153.1, } \\
168.5)\end{array}\end{array}$ & $\begin{array}{l}\text { (138.7, } \\
\text { 154.4, } \\
\quad 170.1)\end{array}$ \\
\hline
\end{tabular}




\section{Minimum Strength with Uncertainty at Full-Scale Component Size (Step 3 of} 3)

In the last section (Step 2: Laboratory-Scale Minimum Strength Estimation), we introduced a DATAPLOT code to compute not only parameters with uncertainty quantification, but also one-sided tolerance limits for 12 coverages ranging from $90 \%$ to $99.99999999 \%$. It turns out that the estimates of the tolerance limits are exactly what we need for step 3 of our new methodology. Here, we need to introduce a new concept, namely, "coverage." As shown by Nelson, et al. [20, pp. 179-180], when the true mean, $\mu$, and standard deviation, $\sigma$, of a normal distribution are not known, the so- called (1- $\alpha) 100 \%$ prediction interval is given by the following expression:

$$
\bar{y} \pm t(\alpha / 2 ; n-1) s \sqrt{ }(1+1 / n),
$$

where $\bar{y}$ is the estimated mean, $s$ is the estimated standard deviation, $n$ is the sample size, $t$ is the wellknown Student's distribution function, and $\alpha$ is the quantity associated with the confidence level given by $(1-\alpha) 100 \%$. For example, a $95 \%$ confidence level is specified by $\alpha=0.05$. For engineers dealing with material testing data, the estimated prediction interval given in Eq. (3) for a normally distributed sample data set is valid only at the sample-scale size.

To extrapolate the sample-scale size estimate to a larger scale, we need the concept of the so-called "coverage," $p$, or, the proportion of the population that is covered by a new statistical interval known as the "tolerance interval," (see again, e.g., Nelson, et al. [20, pp. 179-180]). The upper limit and lower limit of the tolerance interval are known as the upper tolerance limit (UTL) and lower tolerance limit (LTL), respectively. It is the one-sided LTL for a given coverage, $p$, and $(1-\alpha) 100 \%$ confidence level that engineers are interested in for finding the design allowable of a minimum strength for a given structural material. The theory of tolerance intervals for a normal population is well-known in the literature (see, e.g., Prochan [21], Natrella [22], and Nelson, et al. [20]). As shown by Nelson, et al. [20], the tolerance interval for a normal population with a given estimated mean, $\bar{y}$, and standard deviation, $s$, is given below:

$$
\bar{y} \pm r u s,
$$

where the factor, $r(n, p)$, depends on the sample size, $n$, and the coverage, $p$, and the factor, $u(d f, \gamma)$, depends on the degrees of freedom, $d f$, defined by $n-1$, and the confidence level, $\gamma$, defined by $1-\alpha$. Both factors for limited ranges of $n, p$, and $\gamma$, are given in tables of Natrella [22] for two-sided and onesided LTL, and tables of Nelson, et al. [20] for two-sided LTL for a normal population only.

When the underlying distribution is a $3 \mathrm{pW}$, the tolerance interval for a $3 \mathrm{pW}$ population can be estimated using formulas given by Rinne [23, pp. 585-600] and implemented in a computer code we wrote in DATAPLOT [9]. Plots of the tolerance limits at $99 \%$ coverage using the $2 \mathrm{pW}$ and $3 \mathrm{pW}$ models are given in Figs. 7 and 8, respectively. If we define a new metric, "uncertainty," as the ratio of the quantity (upper limit- lower limit) to two times the mean minimum strength, then the uncertainties of the $2 \mathrm{pW}$ and $3 \mathrm{pW}$ minimum strength are given as $30 \%$ and $11 \%$, respectively.

For completeness, we list below the formulas we used (based on Rinne [23]) for implementing the necessary computation in our DATAPLOT code. Following Rinne [23], we used the ML method to estimate the three Weibull parameters, namely, $a$ (location), $b$ (scale), and $c$ (shape). Let $P$ be percentile, and let the coverage, $p$, be given by $1-P$. For example, for $p=0.99$ or a $99 \%$ coverage, $P=0.01$. Instead of Eq. (4) that is applicable only for a normal distribution model, the one-sided lower tolerance interval for a $3 \mathrm{pW}$ population has the following two-term form: 


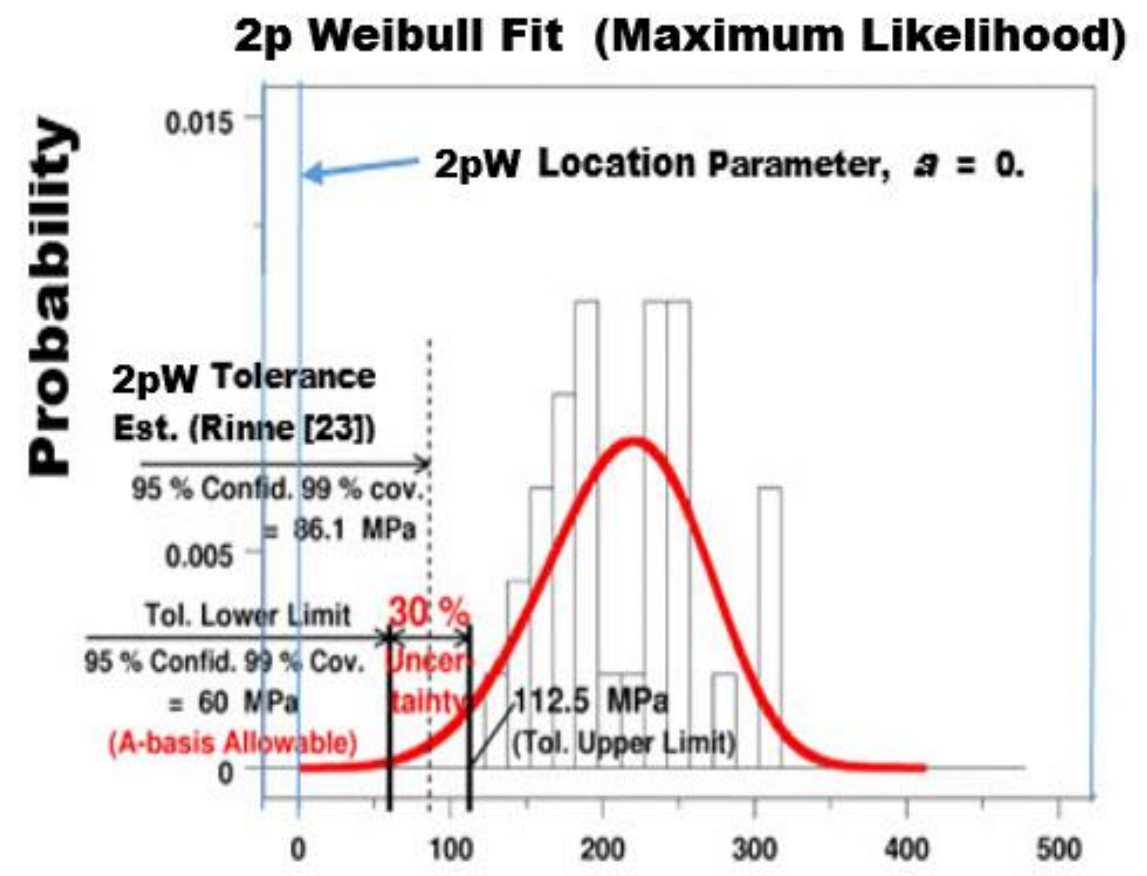

BK-7 Glass Fracture Strength (MPa)

Fig. 7. BK-7 glass: Histogram and fitted 2p Weibull probability density function for the same strength data with lower and upper tolerance limits at $95 \%$ confidence and $99 \%$ coverage (A-basis).

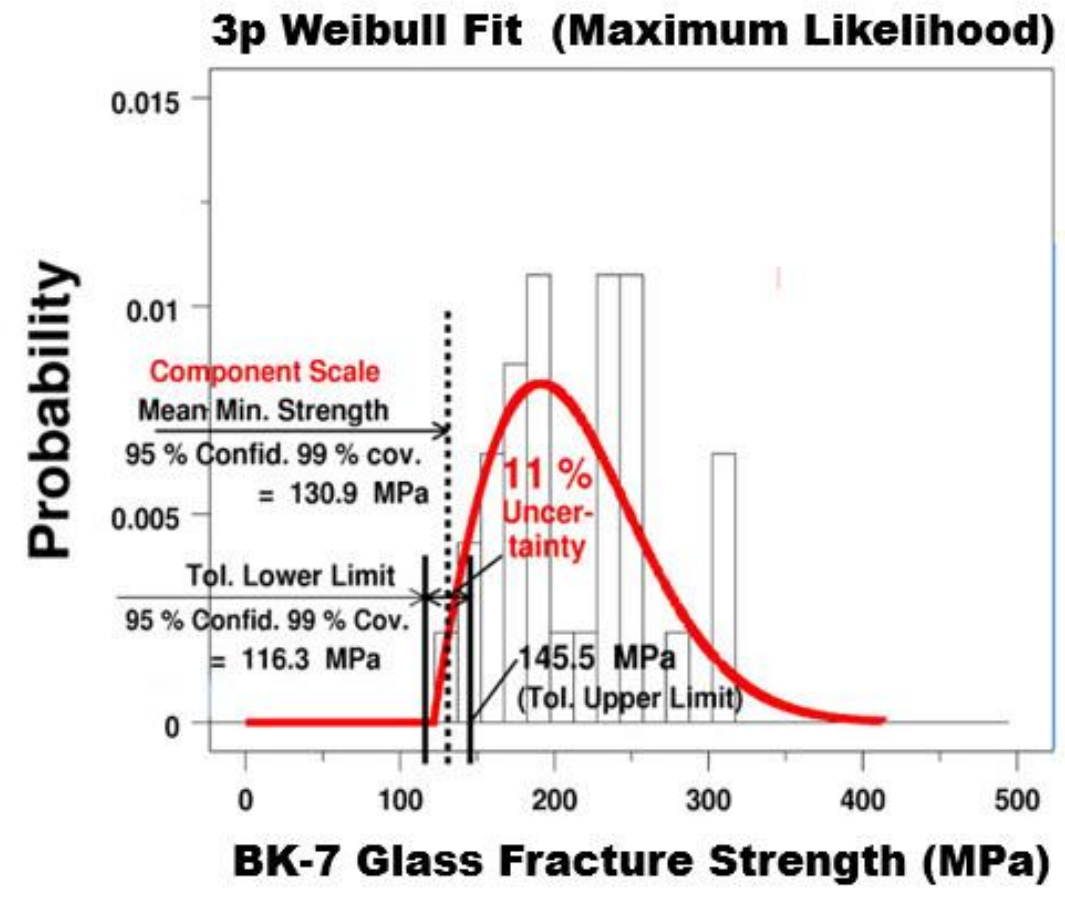

Fig. 8. BK-7 glass: Histogram and fitted 3p Weibull probability density function for the same strength data with lower and upper tolerance limits at $95 \%$ confidence and $99 \%$ coverage (A-basis). 


$$
\hat{x}_{P, L}=\hat{x}_{P}-u_{1-\alpha / 2} \sqrt{\left(A \operatorname{Var}\left(\hat{x}_{P}\right)\right)},
$$

where the first term is given by

$$
\hat{x}_{P}=a+b[-\ln (1-P)]^{1 / c},
$$

and the second term is the product of two factors, the first of which is available from a normal distribution table, and the second of which is given by

$$
A \operatorname{Var}\left(\hat{x}_{P}\right)=\frac{b^{2}}{n D}\left\{\frac{B}{(c-1)^{2}}-\frac{2 \beta^{1 / c}}{c(c-1)}(H+F \ln \beta)+\frac{\beta^{1 / c}}{c^{2}}\left[A-2 G \ln \beta+(\ln \beta)^{2}\right]\right\},
$$

where $\beta=-\ln (1-P)$, and $A, B, D, F, G$, and $H$ are defined in Eqs. (11.12b-h) of Rinne [23].

As a special case when we let the location parameter, $a$, be zero in Eq. (6), we obtain the one-sided lower tolerance interval for a $2 \mathrm{pW}$ population using the same set of Eqs. (5), (6), and (7), shown above, and Eqs. (11.12b-h) of Rinne [23].

In Table 2, we show the values of the so-called A-basis (99\% coverage) design allowable (AbDA) uncertainty for all five models and observe that the AbDA metric correlates well with the composite GoF metric (metric 1). This completes our three-step approach as an alternative to the ASTM standard C1239$07[1]$.

\section{Application of the Three-Step Methodology to Six Sets of Minimum Strength Data}

To show that our new approach is applicable not only to glass, as we did in the previous three sections, but also to other ceramic or metallic materials, we applied the three-step methodology to five more data sets (see Data Set Nos. 2 through 6 in Appendix A). Those data sets came from Duffy, et al. [24], Quinn [25], and NRIM [26], which provided data sets for two more ceramic materials and a metal alloy (a highstrength steel used in the World Trade Center Towers). The complete analysis results for all six sets of data including Data Set No. 1 (glass) are summarized in Table 3.

For completeness, we attach the raw GoF statistics for all six data sets in Appendix B, and the results of the three-step analysis for the remaining five data sets, Data Set Nos. 2 through 6, in Appendices C through G, respectively.

It is interesting to note that Data Set Nos. 2 and 3 are for the same material, silicon nitride $\left(\mathrm{Si}_{3} \mathrm{~N}_{4}\right)$, based on two different tests, namely the four-point bend test (Data Set No. 2), and the biaxial pressurized disk test (Data Set No. 3). Plots of the normalized GoF statistic vs. the six GoF test scenarios in Figs. 9 and 10 for the two data sets clearly shows that the selection of the best-fit model for silicon nitride depends on the test from which the data were generated. If it is from a four-point bend test, the choice is $3 \mathrm{pW}$. If it is from a biaxial test, the choice is normal. The $2 \mathrm{pW}$ function is, nevertheless, not a good choice in either case. For brevity, similar plots for Data Set Nos. 1, 4, 5, and 6 are not included in this paper. 
Journal of Research of the National Institute of Standards and Technology

Model Selection Results for Data Set No. 2 (Si3N4, 4-point-bend test)

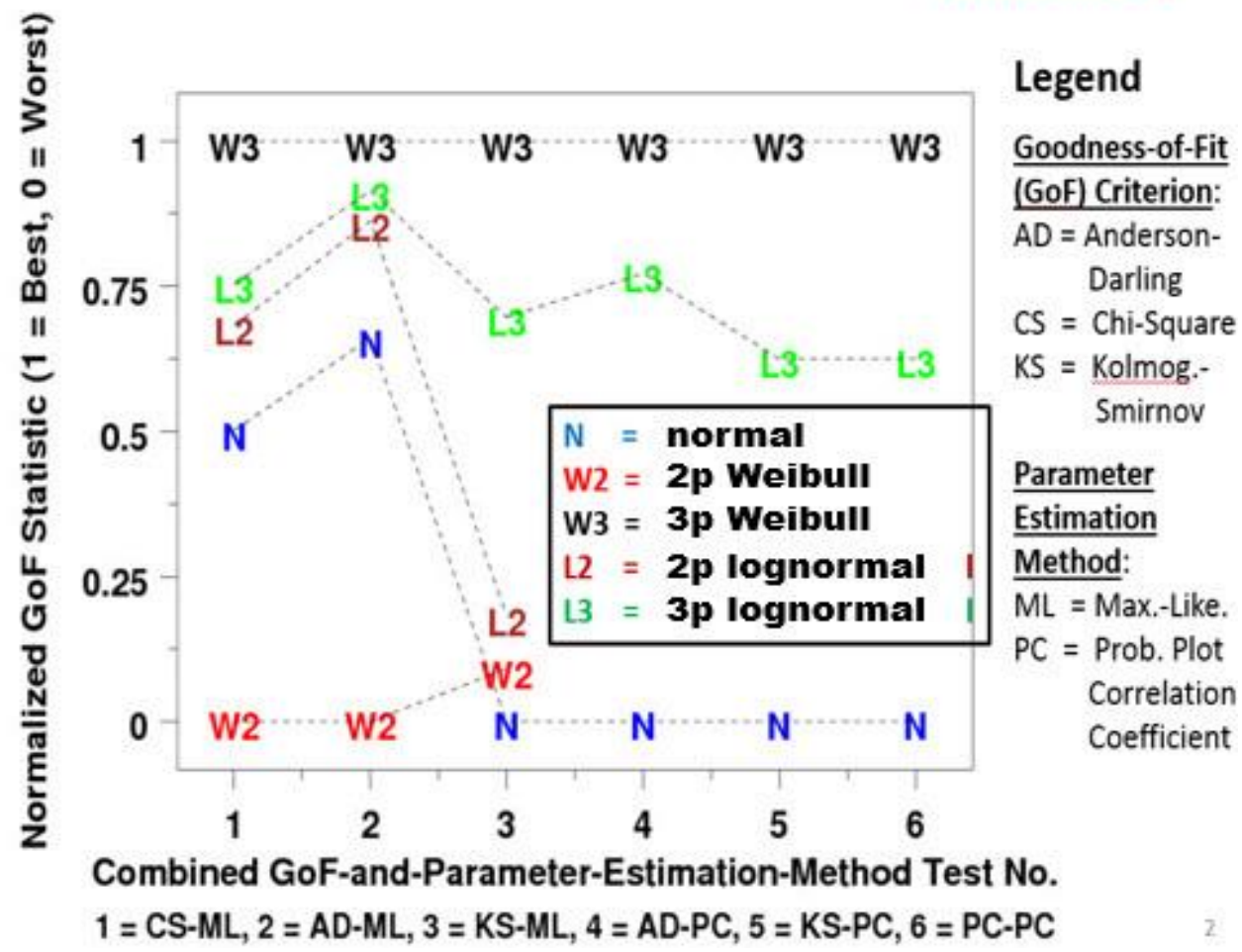

Fig. 9. Silicon nitride $\left(\mathrm{Si}_{3} \mathrm{~N}_{4}\right)$ with a four-point bend test: Model selection results (Data Set No. 2).

Model Selection Results for Data Set No. 3 (Si3N4, biaxial test)

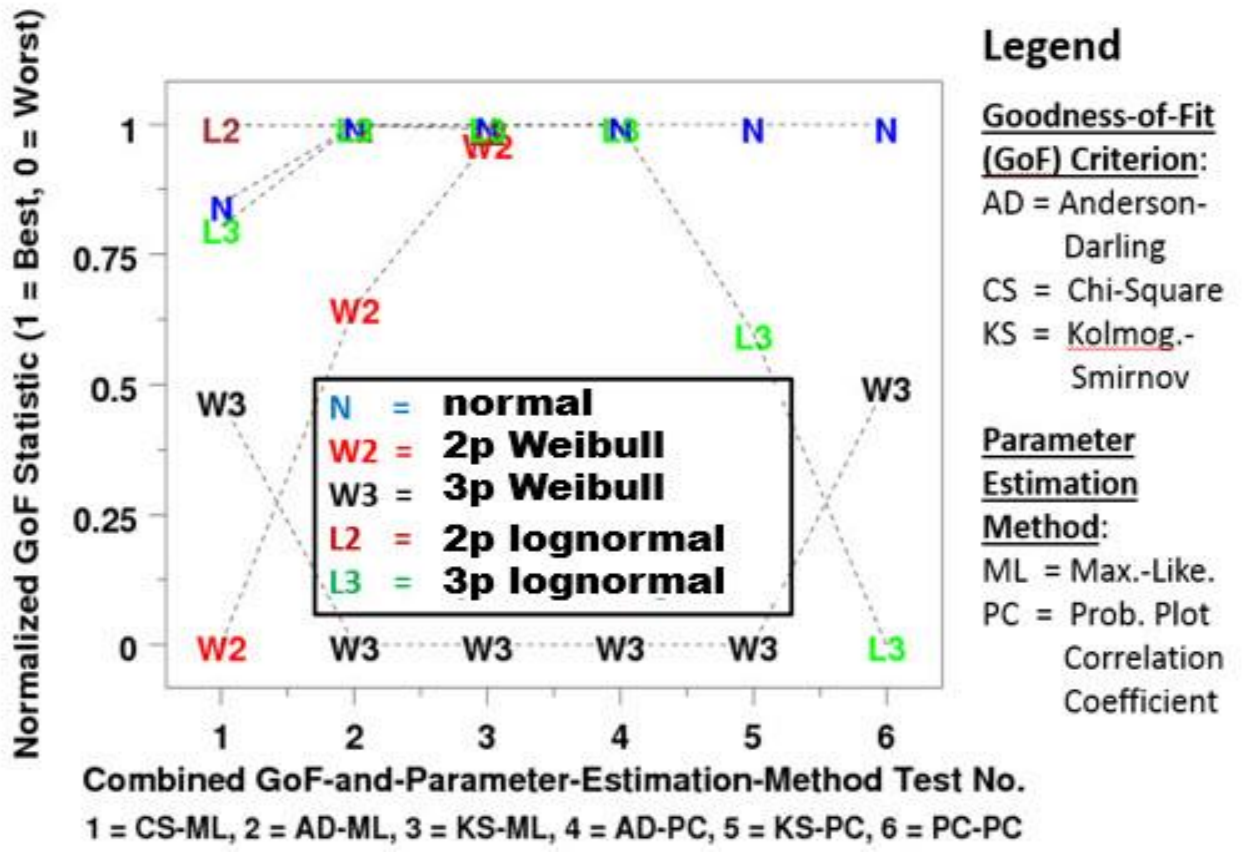

Fig. 10. Silicon nitride $\left(\mathrm{Si}_{3} \mathrm{~N}_{4}\right)$ with a biaxial test: Model selection results (Data Set No. 3). 
Table 3. Model selection results for six data sets of fracture strength of four materials.

\begin{tabular}{|c|c|c|c|c|c|c|c|}
\hline $\begin{array}{c}\text { Data Set No., } \\
\text { Material, } \\
\text { Temperature }\end{array}$ & $\begin{array}{l}\text { Sample Size } \\
\text { Mean } \\
\text { Standard- } \\
\text { Deviation }\end{array}$ & $\begin{array}{c}\text { Metric } \\
\text { No. }\end{array}$ & $\begin{array}{l}\text { Model } 1 \\
\text { Normal }\end{array}$ & $\begin{array}{l}\text { Model } 2 \\
\text { Two- } \\
\text { parameter } \\
\text { Weibull }\end{array}$ & $\begin{array}{l}\text { Model } 3 \\
\text { Three- } \\
\text { parameter } \\
\text { Weibull }\end{array}$ & $\begin{array}{l}\text { Model } 4 \\
\text { Two- } \\
\text { parameter } \\
\text { lognormal }\end{array}$ & $\begin{array}{l}\text { Model } 5 \\
\text { Three- } \\
\text { parameter } \\
\text { lognormal }\end{array}$ \\
\hline $\begin{array}{c}1 . \\
\text { BK-7 glass } \\
20^{\circ} \mathrm{C}\end{array}$ & $\begin{array}{l}31 \\
212.4 \mathrm{MPa} \\
\quad 50.0 \mathrm{MPa}\end{array}$ & $\begin{array}{l}\text { Metric } 1 \\
\qquad \text { Metric } 2 \\
\text { Rank based } \\
\text { on metric } 1\end{array}$ & $\begin{array}{l}38 \% \\
4\end{array}$ & $\begin{array}{l}0 \\
\quad 30 \% \\
\quad 5 \\
\quad \text { (worst) }\end{array}$ & $\begin{array}{l}1.0 \\
\\
\\
\quad 11 \% \\
1 \\
\text { (best) }\end{array}$ & $\begin{array}{l}16 \% \\
2\end{array}$ & $\begin{array}{l}19 \% \\
3\end{array}$ \\
\hline $\begin{array}{c}2 . \\
\text { Silicon } \\
\text { nitride (four- } \\
\text { point bend) } \\
20^{\circ} \mathrm{C}\end{array}$ & $\begin{array}{l}27 \\
733.2 \mathrm{MPa} \\
77.7 \mathrm{MPa}\end{array}$ & $\begin{array}{l}\text { Metric } 1 \\
\qquad \text { Metric } 2 \\
\text { Rank based } \\
\text { on metric } 1\end{array}$ & $11 \%$ & $\begin{array}{l}0.03 \\
15 \% \\
5 \\
\text { (worst) }\end{array}$ & $\begin{array}{l}1.0 \\
\\
\\
\\
\\
1 \\
\text { (best) }\end{array}$ & $13 \%$ & $\begin{array}{r}7 \% \\
2 \quad\end{array}$ \\
\hline $\begin{array}{c}3 . \\
\text { Silicon } \\
\text { nitride (bi- } \\
\text { axial test) } \\
20^{\circ} \mathrm{C}\end{array}$ & $\begin{array}{l}32 \\
688.7 \mathrm{MPa} \\
63.1 \mathrm{MPa}\end{array}$ & $\begin{array}{l}\text { Metric } 1 \\
\qquad \text { Metric } 2 \\
\text { Rank based } \\
\text { on metric } 1\end{array}$ & $\begin{array}{l}0.97 \\
\\
\\
\quad 8 \% \\
1 \\
\text { (best) }\end{array}$ & $\begin{array}{l}12 \% \\
4\end{array}$ & $\begin{array}{l}0.16 \\
12 \% \\
5 \\
\text { (worst) }\end{array}$ & $7 \%$ & $\begin{array}{l}.73 \% \\
3\end{array}$ \\
\hline $\begin{array}{c}4 . \\
\text { Al. oxide } \\
20^{\circ} \mathrm{C}\end{array}$ & $\begin{array}{l}30 \\
\quad 444.0 \mathrm{MPa} \\
\quad 52.1 \mathrm{MPa}\end{array}$ & $\begin{array}{l}\text { Metric } 1 \\
\qquad \text { Metric } 2 \\
\text { Rank based } \\
\text { on metric } 1\end{array}$ & 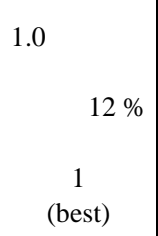 & $\begin{array}{l}16 \% \\
3\end{array}$ & $\begin{array}{l}13 \% \\
4\end{array}$ & $9 \%$ & $\begin{array}{l}0.12 \\
\\
57 \% \\
5 \\
\text { (worst) }\end{array}$ \\
\hline $\begin{array}{c}5 . \\
\text { High- } \\
\text { strength } \\
\text { steel, } 20^{\circ} \mathrm{C}\end{array}$ & $\begin{array}{l}638.3 \\
43.3 \mathrm{MPa}\end{array}$ & $\begin{array}{l}\text { Metric } 1 \\
\qquad \text { Metric } 2 \\
\text { Rank based } \\
\text { on metric } 1\end{array}$ & $7 \%$ & $\begin{array}{c}12 \% \\
5 \\
\text { (worst) }\end{array}$ & $\begin{array}{l}3 \% \\
1 \\
\text { (best) }\end{array}$ & $\begin{array}{l}6 \% \\
3\end{array}$ & $4 \%$ \\
\hline $\begin{array}{c}6 . \\
\text { High- } \\
\text { strength } \\
\text { steel, } 600{ }^{\circ} \mathrm{C}\end{array}$ & $\begin{array}{l}21 \\
300.6 \mathrm{MPa} \\
26.2 \mathrm{MPa}\end{array}$ & $\begin{array}{l}\text { Metric } 1 \\
\qquad \text { Metric } 2 \\
\text { Rank }^{\text {b based }} \\
\text { on metric } 2^{2}\end{array}$ & $\begin{array}{l}10 \% \\
4\end{array}$ & $\begin{array}{l}0.28 \\
15 \% \\
5 \\
\text { (worst) }\end{array}$ & $\begin{array}{c}0.58 \\
\\
\\
\\
1 \\
\\
\text { (best) }\end{array}$ & $\begin{aligned} & 8 \% \\
3 & \end{aligned}$ & $\begin{array}{r}6 \% \\
2 \quad 6\end{array}$ \\
\hline
\end{tabular}

aThe assumption of a zero-location parameter precludes model 4 from being selected as rank 1.

${ }^{b}$ In this special case when we disqualified model 4 for being selected as rank 1 based on metric 1 and found the metric 1 values of model 1 and model 3 too close to call, we switched to the use of metric 2 for ranking the model selection process. 


\section{Significance and Limitations of the Three-Step Minimum Strength Modeling Approach}

The proposed three-step approach outlined in this paper is novel in each of its three steps. In step 1 (Model Selection), we developed a composite normalized GoF statistic named metric 1 to rank and select the "best" model. In step 2 (Laboratory-Scale Modeling), we introduced a method for quantifying the uncertainty of the parameters of each distribution by estimating both their mean value and standard deviation. In step 3 (Component or Structural Full-Scale Modeling), we formulated the concept of an uncertainty metric named metric 2 based on the estimates of the upper and lower tolerance limits of the socalled A-basis design allowable minimum strength. In Table 4, we show the significance of our new approach by comparing the A-basis design allowable minimum strength for the six data sets using either the 2pW (ASTM C1239-07 [1]), or the best-fit choice from our approach. A word of caution needs to be said about the limitations of our approach. First of all, we assumed that the test data are unimodal, and we chose our candidate distributions also to be unimodal, so it is not clear if our approach will be useful if the test data set is not unimodal. Second, we only chose a small set of models, namely five (normal, $2 \mathrm{pW}$, $3 \mathrm{pW}, 2 \mathrm{pLN}$, and $3 \mathrm{pLN}$ ), to work with, and there may be many other distributions that could better fit the data. Nevertheless, since the ASTM C1239-07 suffers the same limitations as outlined above, our approach provides a new and more rational alternative to the current practice.

Table 4. Comparison of the A-basis design allowable minimum strength (MPa) selected from the $2 \mathrm{pW}$ model (ASTM) approach $v s$. our approach by making the best choice among five models according to a goodness-of-fit or tolerance limit uncertainty metric.

\begin{tabular}{|c|c|c|c|}
\hline \multirow[b]{2}{*}{$\begin{array}{l}\text { Data Set (DS) No., Material Name, Temperature } \\
\text { (Type of Strength Test) }\end{array}$} & \multicolumn{2}{|c|}{$\begin{array}{l}\text { "A-Basis" Design Allowable } \\
\text { Minimum Strength (MPa) } \\
\text { (95\% confidence, } 99 \% \text { coverage) }\end{array}$} & \multirow[b]{2}{*}{ Difference } \\
\hline & $\begin{array}{l}\text { 2p Weibull } \\
\text { (ASTM) } \\
\text { Approach }\end{array}$ & Our Approach & \\
\hline $\begin{array}{l}\text { DS- } 1 . \text { BK-7 glass at } 20^{\circ} \mathrm{C} \\
\text { (biaxial test) }\end{array}$ & 60.0 & 116.3 & $+94 \%$ \\
\hline $\begin{array}{l}\text { DS-2. Silicon nitride at } 20^{\circ} \mathrm{C} \\
\text { (four-point bend test) }\end{array}$ & 414.2 & 590.5 & $+43 \%$ \\
\hline $\begin{array}{l}\text { DS-3. Silicon nitride at } 20^{\circ} \mathrm{C} \\
\text { (biaxial test) }\end{array}$ & 432.1 & 487.1 & $+13 \%$ \\
\hline $\begin{array}{l}\text { DS-4. Aluminum oxide at } 20^{\circ} \mathrm{C} \\
\text { (uniaxial test) }\end{array}$ & 239.2 & 275.7 & $+15 \%$ \\
\hline $\begin{array}{l}\text { DS-5. High-strength steel at } 20^{\circ} \mathrm{C} \\
\text { (uniaxial test) }\end{array}$ & 428.5 & 554.9 & $+30 \%$ \\
\hline $\begin{array}{l}\text { DS-6. High-strength steel at } 600{ }^{\circ} \mathrm{C} \\
\text { (uniaxial test) }\end{array}$ & 177.4 & 247.7 & $+40 \%$ \\
\hline
\end{tabular}

It is interesting to note that, for Data Set No. 2, which is shown in bold in Table 6 (Appendix A), another comparison can be made between our result and a $3 p$ Weibull fit to the same data by Duffy, et al. [24], who used a nonlinear regression technique proposed by Margetson and Cooper [27]. The three parameters estimated by Duffy, et al. [24] differ considerably from ours (given in Appendix C) as shown in Table 5: 
Table 5. Comparison of the estimated values of the three parameters of a Weibull distribution chosen to fit a 27 point sample data set (our Data Set No. 2) of a four-point bend fracture strength test of silicon nitride at $20{ }^{\circ} \mathrm{C}$ using the 1992 approach by Duffy, et al [24] and our approach described in this paper.

\begin{tabular}{|l|c|c|c|}
\hline $\begin{array}{c}\text { Modeling Approach Using a } \\
\text { Three-Parameter Weibull Distribution Model }\end{array}$ & $\begin{array}{c}\text { Parameter 1 } \\
\text { (Location) }\end{array}$ & $\begin{array}{c}\text { Parameter 2 } \\
\text { (Scale) }\end{array}$ & $\begin{array}{c}\text { Parameter 3 } \\
\text { (Shape) }\end{array}$ \\
\hline $\begin{array}{l}\text { The 1992 approach by Duffy, } \text { et al. [24] using a nonlinear } \\
\text { regression technique proposed by Margetson and Cooper [27]. }\end{array}$ & 558.1 & 861.6 & 1.68 \\
\hline $\begin{array}{l}\text { Our three-step modeling approach using the maximum likelihood } \\
\text { method of parameter estimation as shown in Appendix C. }\end{array}$ & 603.2 & 145.5 & 1.72 \\
\hline
\end{tabular}

Since ours is based on the maximum likelihood method and four goodness-of-fit statistics criteria that include the Kolmogorov-Smirnov statistic and the Anderson-Darling statistic, both of which happened to be cited by Duffy, et al. [24] as keys to the next best approach after theirs using the nonlinear regression technique, we believe our work provides a direct response to their challenge, and is an improvement over their 1992 results [24].

\section{Concluding Remarks and Future Work}

A three-step approach to improve the ASTM recommended practice C1239-07 for reporting fracture strength data based on the two-parameter Weibull distribution has been formulated and applied not only to ceramics but also to a broader class of materials. Using a six-scenario goodness-of-fit test statistics ranking methodology and the classical theory of tolerance limits to analyze six sets of laboratory data, we succeeded in demonstrating that the two-parameter Weibull distribution is a poor choice to represent strength data in all six cases. In four of the six cases, the best choice among a small set of five candidate models is the three-parameter Weibull distribution, and in two, the best choice is the normal distribution. This leads us to conclude that the two-parameter Weibull, as recommended in ASTM C1239-07, is not a sound choice to represent strength data and to derive minimum strength design allowable properties, and that a statistically sounder approach such as ours is feasible and applicable to at least a large class of brittle materials as represented by the three examples of ceramics and their laboratory test data chosen in this paper.

It is important to note that our approach and the accompanying mathematical rigor were developed specifically for very brittle materials tested in laboratory conditions. Even though we did include one example of a steel at room temperature and another at $600{ }^{\circ} \mathrm{C}$, and our approach appeared to yield the same result as the ceramics, we believe it is premature to conclude its general applicability, since other details may be necessary for high rate loading and elevated temperature environments. By adding more material examples in our future work, we plan to answer the question whether our approach is applicable to a broader class of engineering materials in addition to brittle materials. 


\section{Appendix A: Fracture Failure Test Data of Four Engineering Materials}

Table 6. Six sets of failure strength data for four engineering materials.

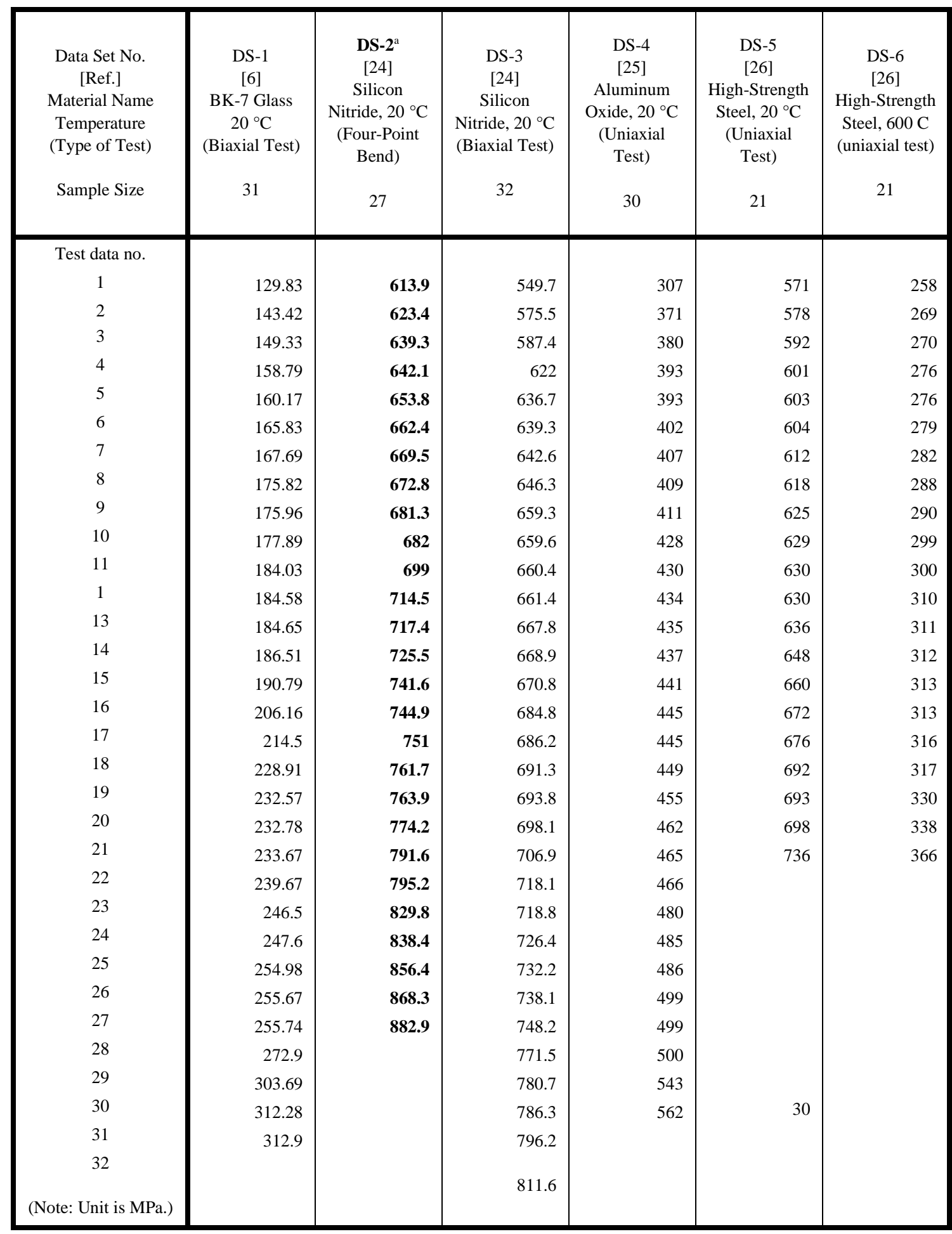

${ }^{a}$ Data Set No. 2 (DS-2) is displayed in bold to bring attention to its association with a statement we made in Sec. 6 regarding a comparison of two approaches to a statistical fit of the data set. 


\section{Appendix B: Raw Goodness-of-Fit Statistics before Normalization for Six Data Sets}

Table 7. Data Sets DS-1, DS-2, and DS-3: Goodness-of-fit statistics for five candidate models.

\begin{tabular}{|c|c|c|c|c|c|c|}
\hline $\begin{array}{l}\text { Goodness-of-Fit (GoF) Criterion and } \\
\text { Parameter Estimation (PE) Method } \\
\text { Combination (Combo) Scenario }\end{array}$ & $\begin{array}{l}\text { GoF/PE } \\
\text { Combo } \\
\text { No. }\end{array}$ & $\begin{array}{l}\text { Model } 1 \\
\text { Normal }\end{array}$ & $\begin{array}{l}\text { Model } 2 \\
\text { Two- } \\
\text { Parameter } \\
\text { Weibull }\end{array}$ & $\begin{array}{l}\text { Model } 3 \\
\text { Three- } \\
\text { Parameter } \\
\text { Weibull }\end{array}$ & $\begin{array}{l}\text { Model } 4 \\
\text { Two- } \\
\text { Parameter } \\
\text { Lognormal }\end{array}$ & $\begin{array}{l}\text { Model } 5 \\
\text { Three- } \\
\text { Parameter } \\
\text { Lognormal }\end{array}$ \\
\hline \multicolumn{7}{|l|}{$\begin{array}{l}\text { DS-1. BK-7 glass at } 20^{\circ} \mathrm{C} \\
\text { (biaxial test) }\end{array}$} \\
\hline $\begin{array}{r}\text { CS-ML. Chi square (CS)-ML } \\
\text { method } 1 \text { combo }\end{array}$ & CS-1 & 13.72 & 13.70 & 10.61 & 11.65 & 11.91 \\
\hline $\begin{array}{r}\text { AD-ML. Anderson-Darling (AD)-ML } \\
\text { method } 1 \text { combo }\end{array}$ & AD-1 & 0.532 & 0.597 & 0.338 & 0.389 & 0.398 \\
\hline $\begin{array}{l}\text { KS-ML. Kolmorogov-Smirnov (KS)- } \\
\text { ML method-1 combo }\end{array}$ & KS-1 & 0.151 & 0.153 & 0.117 & 0.122 & 0.129 \\
\hline $\begin{array}{r}\text { AD-PC. Anderson-Darling (AD)- } \\
\text { PPCC method } 2 \text { combo }\end{array}$ & $\mathrm{AD}-2$ & 0.513 & N.A. ${ }^{a}$ & 0.318 & N.A. & 0.374 \\
\hline $\begin{array}{r}\text { KS-PC. Kolmorogov-Smirnov (KS)- } \\
\text { PPCC method } 2 \text { combo }\end{array}$ & KS-2 & 0.149 & N.A. & 0.114 & N.A. & 0.124 \\
\hline $\begin{array}{r}\text { PC-PC. PPCC (PC) criterion- } \\
\text { PPCC method } 2 \text { combo }\end{array}$ & PC-2 & 0.980 & N.A. & 0.988 & N.A. & 0.986 \\
\hline \multicolumn{7}{|l|}{$\begin{array}{l}\text { DS-2. Silicon nitride at } 20^{\circ} \mathrm{C} \\
\text { (four-point bend test) }\end{array}$} \\
\hline $\begin{array}{r}\text { CS-ML. Chi square (CS)-ML } \\
\text { method } 1 \text { combo }\end{array}$ & CS-1 & 5.372 & 7.065 & 3.692 & 4.761 & 4.522 \\
\hline $\begin{array}{r}\text { AD-ML. Anderson-Darling (AD)-ML } \\
\text { method } 1 \text { combo }\end{array}$ & AD-1 & 0.313 & 0.539 & 0.197 & 0.244 & 0.226 \\
\hline $\begin{array}{r}\text { KS-ML. Kolmorogov-Smirnov (KS)- } \\
\text { ML method-1 combo }\end{array}$ & KS-1 & 0.115 & 0.112 & 0.082 & 0.109 & 0.092 \\
\hline $\begin{array}{r}\text { AD-PC. Anderson-Darling (AD)- } \\
\text { PPCC method } 2 \text { combo }\end{array}$ & AD-2 & 0.289 & N.A. & 0.153 & N.A. & 0.184 \\
\hline $\begin{array}{r}\text { KS-PC. Kolmorogov-Smirnov (KS)- } \\
\text { PPCC method } 2 \text { combo }\end{array}$ & KS-2 & 0.110 & N.A. & 0.086 & N.A. & 0.095 \\
\hline $\begin{array}{r}\text { PC-PC. PPCC (PC) criterion- } \\
\text { PPCC method } 2 \text { combo }\end{array}$ & PC-2 & 0.986 & N.A. & 0.994 & N.A. & 0.991 \\
\hline \multicolumn{7}{|l|}{$\begin{array}{l}\text { DS-3. Silicon nitride at } 20{ }^{\circ} \mathrm{C} \\
\text { (biaxial test) }\end{array}$} \\
\hline $\begin{array}{r}\text { CS-ML. Chi square (CS)-ML } \\
\text { method } 1 \text { combo }\end{array}$ & CS-1 & 4.477 & 6.719 & 5.476 & 4.078 & 4.594 \\
\hline $\begin{array}{r}\text { AD-ML. Anderson-Darling (AD)-ML } \\
\text { method } 1 \text { combo }\end{array}$ & AD-1 & 0.232 & 0.500 & 1.000 & 0.232 & 0.231 \\
\hline $\begin{array}{r}\text { KS-ML. Kolmorogov-Smirnov (KS)- } \\
\text { ML method-1 combo }\end{array}$ & KS-1 & 0.080 & 0.110 & 1.000 & 0.086 & 0.079 \\
\hline $\begin{array}{r}\text { AD-PC. Anderson-Darling (AD)- } \\
\text { PPCC method } 2 \text { combo }\end{array}$ & AD-2 & 0.237 & N.A. & 0.263 & N.A. & 0.237 \\
\hline $\begin{array}{r}\text { KS-PC. Kolmorogov-Smirnov (KS)- } \\
\text { PPCC method } 2 \text { combo }\end{array}$ & KS-2 & 0.087 & N.A. & 0.092 & N.A. & 0.089 \\
\hline $\begin{array}{r}\text { PC-PC. PPCC (PC) criterion- } \\
\text { PPCC method } 2 \text { combo }\end{array}$ & PC-2 & 0.992 & N.A. & 0.991 & N.A. & 0.990 \\
\hline
\end{tabular}

${ }^{a}$ N.A. is not applicable. 


\section{Appendix B (Continued)}

Table 8. Data Sets DS-4, DS-5, and DS-6: Goodness-of-fit statistics for five candidate models.

\begin{tabular}{|c|c|c|c|c|c|c|}
\hline $\begin{array}{l}\text { Goodness-of-Fit (GoF) Criterion and } \\
\text { Parameter Estimation (PE) Method } \\
\text { Combination (Combo) Scenario }\end{array}$ & $\begin{array}{l}\text { GoF/PE } \\
\text { Combo } \\
\text { No. }\end{array}$ & $\begin{array}{l}\text { Model } 1 \\
\text { Normal }\end{array}$ & $\begin{array}{l}\text { Model } 2 \\
\text { Two- } \\
\text { Parameter } \\
\text { Weibull }\end{array}$ & $\begin{array}{l}\text { Model } 3 \\
\text { Three- } \\
\text { Parameter } \\
\text { Weibull }\end{array}$ & $\begin{array}{l}\text { Model } 4 \\
\text { Two- } \\
\text { Parameter } \\
\text { Lognormal }\end{array}$ & $\begin{array}{l}\text { Model } 5 \\
\text { Three- } \\
\text { Parameter } \\
\text { Lognormal }\end{array}$ \\
\hline \multicolumn{7}{|l|}{$\begin{array}{l}\text { DS-4. Aluminum oxide at } 20^{\circ} \mathrm{C} \\
\text { (uniaxial test) }\end{array}$} \\
\hline $\begin{array}{r}\text { CS-ML. Chi square (CS)-ML } \\
\text { method } 1 \text { combo }\end{array}$ & CS-1 & 0.562 & 1.591 & 0.725 & 0.536 & 10.00 \\
\hline $\begin{array}{r}\text { AD-ML. Anderson-Darling (AD)-ML } \\
\text { method } 1 \text { combo }\end{array}$ & $\mathrm{AD}-1$ & 0.232 & 0.472 & 1.000 & 0.293 & 1.000 \\
\hline $\begin{array}{r}\text { KS-ML. Kolmorogov-Smirnov (KS)- } \\
\text { ML method-1 combo }\end{array}$ & KS-1 & 0.080 & 0.106 & 1.000 & 0.102 & 1.000 \\
\hline $\begin{array}{l}\text { AD-PC. Anderson-Darling (AD)- } \\
\text { PPCC method } 2 \text { combo }\end{array}$ & $\mathrm{AD}-2$ & 0.255 & N.A. & 0.309 & N.A. & 0.271 \\
\hline $\begin{array}{r}\text { KS-PC. Kolmorogov-Smirnov (KS)- } \\
\text { PPCC method } 2 \text { combo }\end{array}$ & $\mathrm{KS}-2$ & 0.082 & N.A. & 0.083 & N.A. & 0.097 \\
\hline $\begin{array}{l}\text { PC-PC. PPCC (PC) criterion- } \\
\text { PPCC method } 2 \text { combo }\end{array}$ & PC-2 & 0.985 & N.A. & 0.983 & N.A. & 0.983 \\
\hline \multicolumn{7}{|l|}{$\begin{array}{l}\text { DS-5. High-strength steel } \\
\text { at } 20^{\circ} \mathrm{C} \text { (uniaxial test) }\end{array}$} \\
\hline $\begin{array}{r}\text { CS-ML. Chi square (CS)-ML } \\
\text { method } 1 \text { combo }\end{array}$ & CS-1 & 2.516 & 3.652 & 2.099 & 2.354 & 2.340 \\
\hline $\begin{array}{r}\text { AD-ML. Anderson-Darling (AD)-ML } \\
\text { method } 1 \text { combo }\end{array}$ & AD-1 & 0.328 & 0.603 & 0.187 & 0.273 & 0.188 \\
\hline $\begin{array}{r}\text { KS-ML. Kolmorogov-Smirnov (KS)- } \\
\text { ML method-1 combo }\end{array}$ & KS-1 & 0.147 & 0.173 & 0.090 & 0.136 & 0.095 \\
\hline $\begin{array}{l}\text { AD-PC. Anderson-Darling (AD)- } \\
\text { PPCC method } 2 \text { combo }\end{array}$ & $\mathrm{AD}-2$ & 0.317 & N.A. ${ }^{a}$ & 0.166 & N.A. & 0.190 \\
\hline $\begin{array}{r}\text { KS-PC. Kolmorogov-Smirnov (KS)- } \\
\text { PPCC method } 2 \text { combo }\end{array}$ & $\mathrm{KS}-2$ & 0.145 & N.A. & 0.100 & N.A. & 0.112 \\
\hline $\begin{array}{l}\text { PC-PC. PPCC (PC) criterion- } \\
\text { PPCC method } 2 \text { combo }\end{array}$ & PC-2 & 0.983 & N.A. & 0.995 & N.A. & 0.992 \\
\hline \multicolumn{7}{|l|}{$\begin{array}{l}\text { DS-6. High-strength steel } \\
\text { at } 600^{\circ} \mathrm{C} \text { (uniaxial test) }\end{array}$} \\
\hline $\begin{array}{r}\text { CS-ML. Chi square (CS)-ML } \\
\text { method } 1 \text { combo }\end{array}$ & CS-1 & 1.320 & 2.449 & 10.00 & 1.075 & 10.00 \\
\hline $\begin{array}{r}\text { AD-ML. Anderson-Darling (AD)-ML } \\
\text { method } 1 \text { combo }\end{array}$ & AD-1 & 0.343 & 0.616 & 0.304 & 0.309 & 0.327 \\
\hline $\begin{array}{r}\text { KS-ML. Kolmorogov-Smirnov (KS)- } \\
\text { ML method-1 combo }\end{array}$ & KS-1 & 0.123 & 0.168 & 0.151 & 0.131 & 0.159 \\
\hline $\begin{array}{r}\text { AD-PC. Anderson-Darling (AD)- } \\
\text { PPCC method } 2 \text { combo }\end{array}$ & AD-2 & 0.343 & N.A. & 0.283 & N.A. & 0.293 \\
\hline $\begin{array}{l}\text { KS-PC. Kolmorogov-Smirnov (KS)- } \\
\text { PPCC method } 2 \text { combo }\end{array}$ & $\mathrm{KS}-2$ & 0.129 & N.A. & 0.137 & N.A. & 0.139 \\
\hline $\begin{array}{r}\text { PC-PC. PPCC (PC) criterion- } \\
\text { PPCC method } 2 \text { combo }\end{array}$ & PC-2 & 0.977 & N.A. & 0.984 & N.A. & 0.985 \\
\hline
\end{tabular}




\section{Appendix C: Minimum Strengths of Silicon Nitride $\left(20^{\circ} \mathrm{C}\right)$ of Data Set DS-2}

Table 9. Estimates of minimum strength at laboratory- and full-scale sizes for five candidate models based on Data Set DS-2 (silicon nitride) at $20^{\circ} \mathrm{C}$ (four-point bend test).

\begin{tabular}{|c|c|c|c|c|c|}
\hline & $\begin{array}{l}\text { Model } 1 \\
\text { Normal }\end{array}$ & $\begin{array}{c}\text { Model } 2 \\
2 p \text { Weibull }\end{array}$ & $\begin{array}{c}\text { Model } 3 \\
\text { 3p Weibull }\end{array}$ & $\begin{array}{c}\text { Model } 4 \\
\text { 2p lognormal }\end{array}$ & $\begin{array}{c}\text { Model } 5 \\
\text { 3p lognormal }\end{array}$ \\
\hline \multicolumn{6}{|l|}{ Laboratory-Scale } \\
\hline $\begin{array}{l}\text { Composite normalized } \\
\text { GoF statistic (metric } 1 \text { ) } \\
\text { (Ranges from } 0 \text { to } 1 \text {, } \\
\text { worst to best.) }\end{array}$ & 0.19 & $\begin{array}{c}0.03 \\
\text { (worst) }\end{array}$ & $\begin{array}{l}1.0 \\
\text { (best) }\end{array}$ & 0.58 & 0.73 \\
\hline $\begin{array}{l}\text { Parameter } 1 \text { (Location) } \\
\text { Point estimate of location, } \\
\text { Standard deviation of location }\end{array}$ & 733.2 & None. & 603.2 & None. & 125.2 \\
\hline $\begin{array}{l}\text { One-sided } 95 \% \text { confidence } \\
\text { minimum strength at sample } \\
\text { scale }=(\text { lower limit } \\
\text { point estimate, } \\
\text { upper limit })\end{array}$ & $\begin{array}{l}(546.6, \\
\quad 605.4, \\
\quad 643.0) \\
\end{array}$ & $\begin{array}{l}\text { (512.6, } \\
\quad \begin{array}{l}573.0, \\
633.4)\end{array} \\
\end{array}$ & $\begin{array}{l}(572.8, \\
\quad 603.2 \\
\quad 633.6) \\
\end{array}$ & $\begin{array}{l}\text { (566.7, } \\
\quad 613.6, \\
\quad 645.6) \\
\end{array}$ & $\begin{array}{l}(264.9, \\
\quad 470.9, \\
\quad 676.9) \\
\end{array}$ \\
\hline $\begin{array}{l}\text { Parameter } 2 \text { (Scale) } \\
\text { Point estimate of scale, } \\
\text { Standard deviation of scale }\end{array}$ & 77.7 & 768.5 & 145.5 & 729.3 & 131.6 \\
\hline $\begin{array}{l}\text { Parameter } 3 \text { (Shape) } \\
\text { Point estimate of shape, } \\
\text { Standard deviation of shape }\end{array}$ & None. & 10.1 & 0.415 & 0.105 & 0.159 \\
\hline \multicolumn{6}{|l|}{ Full-Scale Size } \\
\hline $\begin{array}{l}95 \% \text { confidence, } 99 \% \\
\text { coverage A-basis design } \\
\text { allowable (AbDA) } \\
\text { Uncertainty (metric } 2 \text { ) } \\
\text { (Note: Small is good.) }\end{array}$ & $11 \%$ & $\begin{array}{l}15 \% \\
\text { (worst) }\end{array}$ & $\begin{array}{l}4 \% \\
\text { (best) }\end{array}$ & $13 \%$ & $7 \%$ \\
\hline $\begin{array}{l}95 \% \text { confidence, } 99 \% \\
\text { coverage minimum strength at } \\
\text { full scale } \\
\text { ( lower tolerance limit } \\
\text { or A-basis of design, } \\
\text { mean estimate, } \\
\text { upper tolerance limit ) }\end{array}$ & $\begin{array}{l}(476.8, \\
\quad \begin{array}{l}552.4, \\
598.6)\end{array}\end{array}$ & $\begin{array}{l}(414.2, \\
\quad \begin{array}{l}\text { 487.7, } \\
561.2)\end{array}\end{array}$ & $\begin{array}{l}(590.5, \\
\quad 613.2 \\
\quad 635.9)\end{array}$ & $\begin{array}{l}\text { (515.7, } \\
\begin{array}{l}\text { 571.2, } \\
667.3) \\
\end{array}\end{array}$ & 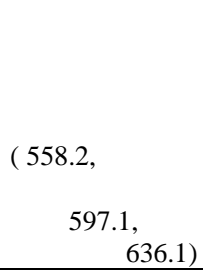 \\
\hline $\begin{array}{l}95 \% \text { confidence, } 90 \% \\
\text { coverage minimum strength at } \\
\text { full scale } \\
\text { ( lower tolerance limit } \\
\text { or B-basis of design, } \\
\text { mean estimate, } \\
\text { upper tolerance limit ) }\end{array}$ & $\begin{array}{l}(583.0, \\
\quad 633.6, \\
\quad 667.4)\end{array}$ & $\begin{array}{l}\text { (562.2, } \\
\quad \begin{array}{l}615.2 \\
\quad 668.2)\end{array}\end{array}$ & $\begin{array}{l}(621.9, \\
\quad 642.4, \\
662.9)\end{array}$ & $\begin{array}{l}\text { (595.3, } \\
\quad \begin{array}{r}637.5, \\
667.3)\end{array}\end{array}$ & $\begin{array}{l}(616.7, \\
642.9, \\
669.0)\end{array}$ \\
\hline
\end{tabular}




\section{Appendix D: Minimum Strengths of Silicon Nitride $\left(20^{\circ} \mathrm{C}\right)$ of Data Set DS-3}

Table 10. Estimates of minimum strength at laboratory- and full-scale sizes for five candidate models based on Data Set DS-3 (silicon nitride) at $20^{\circ} \mathrm{C}$ (biaxial test).

\begin{tabular}{|c|c|c|c|c|c|}
\hline & $\begin{array}{l}\text { Model } 1 \\
\text { Normal }\end{array}$ & $\begin{array}{c}\text { Model 2 } \\
\text { 2p Weibull }\end{array}$ & $\begin{array}{c}\text { Model 3 } \\
\text { 3p Weibull }\end{array}$ & $\begin{array}{c}\text { Model } 4 \\
\text { 2p lognormal }\end{array}$ & $\begin{array}{c}\text { Model } 5 \\
\text { 3p lognormal }\end{array}$ \\
\hline \multicolumn{6}{|l|}{ Laboratory-Scale } \\
\hline $\begin{array}{l}\text { Composite normalized } \\
\text { GoF statistic (metric } 1 \text { ) } \\
\text { (Ranges from } 0 \text { to } 1, \\
\text { worst to best.) }\end{array}$ & $\begin{array}{l}0.97 \\
\text { (best) }\end{array}$ & 0.54 & $\begin{array}{c}0.16 \\
\text { (worst) }\end{array}$ & $\begin{array}{l}\text { (Disqualified. } \\
\text { See Table } 3 \text { for } \\
\text { more details.) }\end{array}$ & 0.73 \\
\hline $\begin{array}{l}\text { Parameter } 1 \text { (Location) } \\
\text { Point estimate of location, } \\
\text { Standard deviation of location }\end{array}$ & 688.7 & None. & 402.5 & None. & -3096. \\
\hline $\begin{array}{l}\text { One-sided } 95 \% \text { confidence } \\
\text { minimum strength at sample } \\
\text { scale = ( lower limit, } \\
\text { point estimate, } \\
\text { upper limit })\end{array}$ & $\begin{array}{l}(542.2, \\
\quad 584.9, \\
\quad 613.3)\end{array}$ & $\begin{array}{l}(514.4, \\
\quad 560.1, \\
\quad 605.8)\end{array}$ & $\begin{array}{l}(160.9, \\
\quad 402.5, \\
\quad 644.1)\end{array}$ & $\begin{array}{l}(553.3, \\
\quad 589.0 \\
\quad 614.1) \\
\end{array}$ & $\begin{array}{l}\text { Negative } \\
\text { Value }\end{array}$ \\
\hline $\begin{array}{l}\text { Parameter } 2 \text { (Scale) } \\
\text { Point estimate of scale, } \\
\text { Standard deviation of scale }\end{array}$ & 63.1 & 717.1 & 150.6 & 685.8 & $\begin{array}{l}3784 . \\
\text { (Not available.) }\end{array}$ \\
\hline $\begin{array}{l}\text { Parameter } 3 \text { (Shape) } \\
\text { Point estimate of shape, } \\
\text { Standard deviation of shape }\end{array}$ & None. & 12.02 & 2.65 & 0.092 & $\begin{array}{l}0.016 \\
\text { (Not available.) }\end{array}$ \\
\hline \multicolumn{6}{|l|}{ Full-Scale Size } \\
\hline $\begin{array}{l}95 \% \text { confidence, } 99 \% \\
\text { coverage A-basis design } \\
\text { allowable (AbDA) } \\
\text { Uncertainty (metric } 2 \text { ) } \\
\text { (Note: Small is good.) }\end{array}$ & $\begin{array}{l}8 \% \\
\text { (best) }\end{array}$ & $\begin{array}{l}12 \% \\
\text { (worst) }\end{array}$ & $\begin{array}{l}12 \% \\
\text { (worst) }\end{array}$ & $\begin{array}{l}\text { (Disqualified. } \\
\text { See Table } 3 \text { for } \\
\text { more details.) }\end{array}$ & $10 \%$ \\
\hline $\begin{array}{l}95 \% \text { confidence, } 99 \% \\
\text { coverage minimum strength at } \\
\text { full scale } \\
\text { ( lower tolerance limit } \\
\text { or A-basis of design, } \\
\text { mean estimate, } \\
\text { upper tolerance limit ) }\end{array}$ & $\begin{array}{l}(487.1, \\
\quad \begin{array}{l}541.9 \\
576.8) \\
\end{array}\end{array}$ & $\begin{array}{l}\text { (432.1, } \\
\begin{array}{l}\text { 489.1, } \\
\text { 546.1) }\end{array}\end{array}$ & $\begin{array}{l}(469.3, \\
\quad 531.2, \\
\quad 593.0) \\
\end{array}$ & $\begin{array}{l}(510.3, \\
\quad 553.0, \\
\quad 582.1) \\
\end{array}$ & $\begin{array}{l}(491.6, \\
\quad 546.4, \\
601.2)\end{array}$ \\
\hline $\begin{array}{l}95 \% \text { confidence, } 90 \% \\
\text { coverage minimum strength at } \\
\text { full scale } \\
\text { ( lower tolerance limit } \\
\text { or B-basis of design, } \\
\text { mean estimate, } \\
\text { upper tolerance limit ) }\end{array}$ & $\begin{array}{l}(571.0, \\
\quad 607.8, \\
\quad 633.3)\end{array}$ & $\begin{array}{l}(555.0, \\
\quad 594.7, \\
\quad 634.3)\end{array}$ & $\begin{array}{l}(572.2, \\
\quad 604.4, \\
\quad 636.6)\end{array}$ & $\begin{array}{l}\text { (577.1, } \\
\quad \begin{array}{l}\text { 609.1, } \\
\quad 632.3)\end{array}\end{array}$ & $\begin{array}{l}(580.4, \\
609.4, \\
638.3)\end{array}$ \\
\hline
\end{tabular}




\section{Appendix E: Minimum Strengths of Aluminum Oxide $\left(20^{\circ} \mathrm{C}\right)$ of Data Set DS-4}

Table 11. Estimates of minimum strength at laboratory- and full-scale sizes for five candidate models based on Data Set DS-4 (aluminum oxide) at $20^{\circ} \mathrm{C}$ (uniaxial test).

\begin{tabular}{|c|c|c|c|c|c|}
\hline & $\begin{array}{l}\text { Model } 1 \\
\text { Normal }\end{array}$ & $\begin{array}{c}\text { Model 2 } \\
\text { 2p Weibull }\end{array}$ & $\begin{array}{c}\text { Model 3 } \\
\text { 3p Weibull }\end{array}$ & $\begin{array}{c}\text { Model } 4 \\
2 p \text { lognormal }\end{array}$ & $\begin{array}{c}\text { Model 5 } \\
\text { 3p lognormal }\end{array}$ \\
\hline \multicolumn{6}{|l|}{ Laboratory-Scale } \\
\hline $\begin{array}{l}\text { Composite normalized } \\
\text { GoF statistic (metric } 1 \text { ) } \\
\text { (Ranges from } 0 \text { to } 1 \text {, } \\
\text { worst to best.) }\end{array}$ & $\begin{array}{c}1.0 \\
\text { (best) }\end{array}$ & 0.88 & 0.32 & 0.97 & $\begin{array}{c}0.12 \\
\text { (worst) }\end{array}$ \\
\hline $\begin{array}{l}\text { Parameter } 1 \text { (Location) } \\
\text { Point estimate of location, } \\
\text { Standard deviation of location }\end{array}$ & 444.0 & None. & 258.3 & None. & $\begin{array}{l}-1331 . \\
\text { (Not available.) }\end{array}$ \\
\hline $\begin{array}{l}\text { One-sided } 95 \% \text { confidence } \\
\text { minimum strength at sample } \\
\text { scale }=(\text { lower limit } \\
\text { point estimate } \\
\text { upper limit })\end{array}$ & $\begin{array}{l}(321.6, \\
\quad 358.3 \\
\quad 382.4)\end{array}$ & $\begin{array}{l}\left(\begin{array}{l}301.3 \\
338.3 \\
\quad 375.4)\end{array}\right.\end{array}$ & $\begin{array}{l}(147.9, \\
\quad 258.3, \\
\quad 368.6)\end{array}$ & $\begin{array}{l}(332.2 \\
\quad 361.7 \\
\quad 382.4)\end{array}$ & $\begin{array}{c}\text { (Not } \\
\text { Available.) }\end{array}$ \\
\hline $\begin{array}{l}\text { Parameter } 2 \text { (Scale) } \\
\text { Point estimate of scale, } \\
\text { Standard deviation of scale }\end{array}$ & 52.1 & 466.6 & 204.9 & 440.9 & $\begin{array}{l}1775 . \\
\text { (Not available.) }\end{array}$ \\
\hline $\begin{array}{l}\text { Parameter } 3 \text { (Shape) } \\
\text { Point estimate of shape, } \\
\text { Standard deviation of shape }\end{array}$ & None. & 9.24 & 1.53 & $\begin{array}{r}0.12 \\
\\
\\
\\
\end{array}$ & $\begin{array}{l}0.29 \\
\text { (Not available.) }\end{array}$ \\
\hline Full-Scale Size & & & & & \\
\hline $\begin{array}{l}95 \% \text { confidence, } 99 \% \\
\text { coverage A-basis design } \\
\text { allowable (AbDA) } \\
\text { Uncertainty (metric } 2 \text { ) } \\
\text { (Note: Small is good.) }\end{array}$ & $12 \%$ & $16 \%$ & $13 \%$ & $9 \%$ & $57 \%$ \\
\hline $\begin{array}{l}95 \% \text { confidence, } 99 \% \\
\text { coverage minimum strength at } \\
\text { full scale } \\
\text { ( lower tolerance limit } \\
\text { or A-basis of design, } \\
\text { mean estimate, } \\
\text { upper tolerance limit ) }\end{array}$ & $\begin{array}{l}(275.7, \\
\quad \begin{array}{l}322.9, \\
\quad 352.5) \\
\end{array}\end{array}$ & $\begin{array}{l}(239.2, \\
\quad 283.6, \\
\quad 328.0) \\
\end{array}$ & $\begin{array}{l}(282.1, \\
\quad 323.2, \\
\quad 364.3) \\
\end{array}$ & $\begin{array}{l}(298.7, \\
\quad 333.1, \\
\quad 356.8) \\
\end{array}$ & $\begin{array}{c}\text { (Not } \\
\text { Available.) }\end{array}$ \\
\hline $\begin{array}{l}95 \% \text { confidence, } 90 \% \\
\text { coverage minimum strength at } \\
\text { full scale } \\
\text { ( lower tolerance limit } \\
\text { or B-basis of design, } \\
\text { mean estimate, } \\
\text { upper tolerance limit ) }\end{array}$ & $\begin{array}{l}(345.6, \\
\quad \begin{array}{l}377.3, \\
398.9)\end{array}\end{array}$ & $\begin{array}{l}(333.0, \\
\quad 365.8, \\
\quad 398.5)\end{array}$ & $\begin{array}{l}(350.2, \\
\quad 375.0, \\
\quad 399.8)\end{array}$ & $\begin{array}{l}(351.2, \\
\quad 377.8, \\
\quad 397.2)\end{array}$ & $\begin{array}{c}\text { (Not } \\
\text { available.) }\end{array}$ \\
\hline
\end{tabular}




\section{Appendix F: Minimum Strengths of a High-Strength Steel $\left(20^{\circ} \mathrm{C}\right)$ of Data Set DS-5}

Table 12. Estimates of minimum strength at laboratory- and full-scale sizes for five candidate models based on Data Set DS-5 (highstrength steel) at $20^{\circ} \mathrm{C}$ (uniaxial test).

\begin{tabular}{|c|c|c|c|c|c|}
\hline & $\begin{array}{l}\text { Model } 1 \\
\text { Normal }\end{array}$ & $\begin{array}{c}\text { Model } 2 \\
2 p \text { Weibull }\end{array}$ & $\begin{array}{c}\text { Model } 3 \\
\text { 3p Weibull }\end{array}$ & $\begin{array}{c}\text { Model } 4 \\
\text { 2p lognormal }\end{array}$ & $\begin{array}{c}\text { Model } 5 \\
\text { 3p lognormal }\end{array}$ \\
\hline \multicolumn{6}{|l|}{ Laboratory-Scale } \\
\hline $\begin{array}{l}\text { Composite normalized } \\
\text { GoF statistic (metric } 1 \text { ) } \\
\text { (Ranges from } 0 \text { to } 1 \text {, } \\
\text { worst to best.) }\end{array}$ & 0.28 & $\begin{array}{c}0 \\
\text { (worst) }\end{array}$ & $\begin{array}{c}1.0 \\
\text { (best) }\end{array}$ & 0.69 & 0.85 \\
\hline $\begin{array}{l}\text { Parameter } 1 \text { (Location) } \\
\text { Point estimate of location, } \\
\text { Standard deviation of location }\end{array}$ & 538.3 & None. & 563.5 & None. & 494.2 \\
\hline $\begin{array}{l}\text { One-sided } 95 \% \text { confidence } \\
\text { minimum strength at sample } \\
\text { scale }=(\text { lower limit } \\
\text { point estimate } \\
\text { upper limit })\end{array}$ & $\begin{array}{l}(527.8, \\
\quad 566.8, \\
\quad 590.2)\end{array}$ & $\begin{array}{l}(496.6, \\
\quad 540.2, \\
\quad 583.9)\end{array}$ & $\begin{array}{l}(543.2, \\
\quad 563.5, \\
\quad 583.9)\end{array}$ & $\begin{array}{l}(536.8, \\
\quad 570.2 \\
\quad 591.2)\end{array}$ & $\begin{array}{l}(366.2, \\
\quad 494.2, \\
622.3)\end{array}$ \\
\hline $\begin{array}{l}\text { Parameter } 2 \text { (Scale) } \\
\text { Point estimate of scale, } \\
\text { Standard deviation of scale }\end{array}$ & 43.4 & 658.8 & 83.9 & 636.9 & 81.8 \\
\hline $\begin{array}{l}\text { Parameter } 3 \text { (Shape) } \\
\text { Point estimate of shape, } \\
\text { Standard deviation of shape }\end{array}$ & None. & 15.0 & 0.53 & 0.011 & 0.181 \\
\hline \multicolumn{6}{|l|}{ Full-Scale Size } \\
\hline $\begin{array}{l}95 \% \text { confidence, } 99 \% \\
\text { coverage A-basis design } \\
\text { allowable (AbDA) } \\
\text { Uncertainty (metric } 2 \text { ) } \\
\text { (Note: Small is good.) }\end{array}$ & $7 \%$ & $\begin{array}{c}12 \% \\
\text { (worst) }\end{array}$ & $\begin{array}{l}3 \% \\
\text { (best) }\end{array}$ & $6 \%$ & $4 \%$ \\
\hline $\begin{array}{l}95 \% \text { confidence, } 99 \% \\
\text { coverage minimum strength at } \\
\text { full scale } \\
\text { ( lower tolerance limit } \\
\text { or A-basis of design, } \\
\text { mean estimate, } \\
\text { upper tolerance limit ) }\end{array}$ & $\begin{array}{l}(486.8, \\
\quad 537.2, \\
\quad 565.9) \\
\end{array}$ & $\begin{array}{l}(428.5, \\
\quad 484.5, \\
\quad 540.5) \\
\end{array}$ & $\begin{array}{l}(554.9, \\
\quad \begin{array}{l}570.1, \\
585.2) \\
\end{array}\end{array}$ & $\begin{array}{l}(503.8, \\
\quad 544.7, \\
\quad 569.4) \\
\end{array}$ & $\begin{array}{l}(539.2, \\
\quad 563.5, \\
587.7) \\
\end{array}$ \\
\hline $\begin{array}{l}95 \% \text { confidence, } 90 \% \\
\text { coverage minimum strength at } \\
\text { full scale } \\
\text { ( lower tolerance limit } \\
\text { or B-basis of design, } \\
\text { mean estimate, } \\
\text { upper tolerance limit ) }\end{array}$ & $\begin{array}{l}(549.1, \\
\quad 582.6, \\
\quad 603.7)\end{array}$ & $\begin{array}{l}(529.4, \\
\quad 566.9, \\
\quad 604.3)\end{array}$ & $\begin{array}{l}(574.2, \\
\quad 587.6, \\
601.0)\end{array}$ & $\begin{array}{l}(554.8, \\
\quad \begin{array}{l}584.3 \\
\quad 605.7)\end{array}\end{array}$ & $\begin{array}{l}(572.3, \\
\quad 588.6, \\
604.9)\end{array}$ \\
\hline
\end{tabular}




\section{Appendix G: Minimum Strengths of a High-Strength Steel $\left(600^{\circ} \mathrm{C}\right)$ of Data Set DS-6}

Table 13. Estimates of minimum strength at laboratory- and full-scale sizes for five candidate models based on Data Set DS-6 (highstrength steel) at $600^{\circ} \mathrm{C}$ (uniaxial test).

\begin{tabular}{|c|c|c|c|c|c|}
\hline & $\begin{array}{l}\text { Model } 1 \\
\text { Normal }\end{array}$ & $\begin{array}{c}\text { Model } 2 \\
2 p \text { Weibull }\end{array}$ & $\begin{array}{c}\text { Model } 3 \\
\text { 3p Weibull }\end{array}$ & $\begin{array}{c}\text { Model } 4 \\
\text { 2p lognormal }\end{array}$ & $\begin{array}{c}\text { Model } 5 \\
\text { 3p lognormal }\end{array}$ \\
\hline \multicolumn{6}{|l|}{ Laboratory-Scale } \\
\hline $\begin{array}{l}\text { Composite normalized } \\
\text { GoF statistic (metric } 1 \text { ) } \\
\text { (Ranges from } 0 \text { to } 1 \text {, } \\
\text { worst to best.) }\end{array}$ & 0.64 & 0.28 & 0.58 & $\begin{array}{l}\text { (Disqualified. } \\
\text { See Table } 3 \text { for } \\
\text { more details.) }\end{array}$ & 0.49 \\
\hline $\begin{array}{l}\text { Parameter } 1 \text { (Location) } \\
\text { Point estimate of location, } \\
\text { Standard deviation of location }\end{array}$ & 300.6 & None. & 252.6 & None. & 197.5 \\
\hline $\begin{array}{l}\text { One-sided } 95 \% \text { confidence } \\
\text { minimum strength at sample } \\
\text { scale }=(\text { lower limit } \\
\text { point estimate, } \\
\text { upper limit })\end{array}$ & $\begin{array}{l}(234.0, \\
\quad 257.5, \\
\quad 271.6)\end{array}$ & $\begin{array}{l}(215.6, \\
\quad 241.1, \\
\quad 266.7)\end{array}$ & $\begin{array}{l}(238.8, \\
\quad 252.6, \\
\quad 266.5)\end{array}$ & $\begin{array}{l}(240.7, \\
\quad 260.1, \\
\quad 272.4)\end{array}$ & $\begin{array}{l}\text { (84.4, } \\
\quad \begin{array}{l}\text { 197.5, } \\
310.6)\end{array}\end{array}$ \\
\hline $\begin{array}{l}\text { Parameter } 2 \text { (Scale) } \\
\text { Point estimate of scale, } \\
\text { Standard deviation of scale }\end{array}$ & 26.2 & 312.7 & 54.0 & 299.6 & 71.1 \\
\hline $\begin{array}{l}\text { Parameter } 3 \text { (Shape) } \\
\text { Point estimate of shape, } \\
\text { Standard deviation of shape }\end{array}$ & None. & 11.4 & 1.91 & 0.086 & 0.18 \\
\hline \multicolumn{6}{|l|}{ Full-Scale Size } \\
\hline $\begin{array}{l}95 \% \text { confidence, } 99 \% \\
\text { coverage A-basis design } \\
\text { allowable (AbDA) } \\
\text { Uncertainty (metric } 2 \text { ) } \\
\text { (Note: Small is good.) }\end{array}$ & $10 \%$ & $15 \%$ & $\begin{array}{l}4 \% \\
\text { (best) }\end{array}$ & $8 \%$ & $6 \%$ \\
\hline $\begin{array}{l}95 \% \text { confidence, } 99 \% \\
\text { coverage minimum strength at } \\
\text { full scale } \\
\text { ( lower tolerance limit } \\
\text { or A-basis of design, } \\
\text { mean estimate, } \\
\text { upper tolerance limit ) }\end{array}$ & $\begin{array}{l}(209.3, \\
\quad 239.7, \\
\quad 256.9) \\
\end{array}$ & $\begin{array}{l}\text { (177.4, } \\
\begin{array}{l}\text { 209.1, } \\
240.7) \\
\end{array}\end{array}$ & $\begin{array}{l}\text { (247.7, } \\
\text { 257.7, } \\
\quad 267.7) \\
\end{array}$ & $\begin{array}{l}(222.0, \\
\quad \begin{array}{r}245.3 \\
259.6) \\
\end{array}\end{array}$ & $\begin{array}{l}\text { (237.3, } \\
\begin{array}{r}253.7 \\
270.1)\end{array}\end{array}$ \\
\hline $\begin{array}{l}95 \% \text { confidence, } 90 \% \\
\text { coverage minimum strength at } \\
\text { full scale } \\
\text { ( lower tolerance limit } \\
\text { or B-basis of design, } \\
\text { mean estimate, } \\
\text { upper tolerance limit ) }\end{array}$ & $\begin{array}{l}(246.8, \\
\quad 267.0, \\
\quad 279.8)\end{array}$ & $\begin{array}{l}(234.6, \\
\quad 256.8, \\
\quad 279.0)\end{array}$ & $\begin{array}{l}(260.9, \\
269.6, \\
\quad 278.4)\end{array}$ & $\begin{array}{l}(251.1, \\
\quad 268.3, \\
\quad 279.8)\end{array}$ & $\begin{array}{l}(259.8, \\
\begin{array}{l}270.3, \\
280.8)\end{array}\end{array}$ \\
\hline
\end{tabular}




\section{Acknowledgments}

We wish to thank Dr. Dennis Leber of the Statistical Engineering Division, National Institute of Standards and Technology (NIST), for valuable comments on an earlier draft of this manuscript, which led to a substantial improvement in the presentation of this paper.

\section{References}

[1] ASTM International (2008) ASTM Designation: C1239-07-Standard practice for reporting uniaxial strength data and estimating Weibull distribution parameters for advanced ceramics. Committee C28 on Advanced Ceramics, reapproved 2008 (ASTM International, West Conshohocken, PA). https://doi.org/10.1520/C1239-07

[2] Mann NR, Schafer RE, Singpurwalla ND (1974) Methods for Statistical Analysis of Reliability and Life Data (Wiley, New York).

[3] Nelson WB (1982) Applied Life Data Analysis (Wiley, New York). https://doi.org/10.1002/0471725234

[4] Lawless JF (2003) Statistical Models and Methods for Lifetime Data (Wiley, New York), 2nd Ed. https://doi.org/10.1002/9781118033005

[5] Anonymous (2002) Statistical Methods. MIL-HDBK-17 Composite Materials Handbook Volume 1: Guidelines for Characterization of Structural Materials (U.S. Department of Defense, Washington, DC), Chapter 8.

[6] Fuller Jr. ER, Freiman SW, Quinn JB, Quinn GD, Carter WC (1994) Fracture mechanics approach to the design of glass aircraft windows: A case study. SPIE Proceedings 2286, 419-430. https://doi.org/10.1117/12.187363

[7] Aldrich J (1997) R. A. Fisher and the making of maximum likelihood 1912-1922. Statistical Science 12(3):162--176. https://doi.org/10.1214/ss/1030037906

[8] Anderson DR (2008) Appendix A. Likelihood theory. Model Based Inference in the Life Sciences: A Primer on Evidence (Springer, New York), pp 147-154. https://doi.org/10.1007/978-0-387-74075-1

[9] Filliben JJ, Heckert NA (2002) Dataplot: A Statistical Data Analysis Software System (National Institute of Standards and Technology, Gaithersburg, MD). Available at http://www.itl.nist.gov/div898/software/dataplot.html

[10] Bury KV (1975) Statistical Models in Applied Science (Wiley, New York).

[11] Filliben JJ (1969) Simple and Robust Linear Estimation of the Location Parameter of a Symmetric Distribution. Ph.D. thesis, Princeton University, Princeton, NJ.

[12] Filliben JJ (1975) The probability plot correlation coefficient test for normality. Technometrics 17(1):111-117 https://doi.org/10.1080/00401706.1975.10489279

[13] Looney SW, Gulledge Jr. TR (1985) Use of the correlation coefficient with normal probability plots The American Statistician 39(1):75-79. https://doi.org/10.2307/2683917

[14] Vogel RM (1986) The probability plot correlation coefficient test for the normal, log-normal, and Gumbel distributional hypotheses. Water Resources Research 22(4):587-590. https://doi.org/10.1029/WR022i004p00587

[15] Anderson TW, Darling DA (1952) Asymptotic theory of certain 'goodness of fit' criteria based on stochastic processes. Annals of Mathematical Statistics 23:193-212. https://doi.org/10.1214/aoms/1177729437

[16] Anderson TW, Darling DA (1954) A test of goodness of fit. Journal of the American Statistical Association 49:765-769. https://doi.org/10.2307/2281537

[17] Cohen AC, Whitten BJ (1988) Parameter Estimation in Reliability and Life Span Models (CRC Press, Boca Raton, FL). https://doi.org/10.1201/9781003066064

[18] Bury K (1999) Statistical Distributions in Engineering (Cambridge University Press, Cambridge, U.K.). https://doi.org/10.1017/CBO9781139175081

[19] McCool JI (2012) Using the Weibull Distribution: Reliability, Modeling, \& Inference (Wiley, New York). https://doi.org/10.1002/9781118351994

[20] Nelson PR, Coffin M, Copeland KAF (2003) Introductory Statistics for Engineering Experimentation (Elsevier Academic Press, London). https://doi.org/10.1016/B978-0-12-515423-9.X5000-6

[21] Prochan F (1953) Confidence and tolerance intervals for the normal distribution Journal of the American Statistical Association 48:550-564. https://doi.org/10.2307/2281009

[22] Natrella MG (1966) Experimental Statistics (Aug. 1, 1963, reprinted with corrections Oct. 1966) (Superintendent of Documents, U.S. Government Printing Office, Washington, DC), National Bureau of Standards Handbook 91, pp 1-14, 1-15, 2-13, 2-14, and 2-15, Tables A-6 and A-7. https://doi.org/10.6028/NBS.HB.91

[23] Rinne H (2009) The Weibull Distribution, A Handbook (Chapman \& Hall/CRC, Taylor \& Francis Group, Boca Raton, FL). https://doi.org/10.1201/9781420087444

[24] Duffy S, Powers LM, Starlinger A (1992) Reliability analysis of structural ceramic components using a three-parameter Weibul distribution. Civil and Environmental Engineering Faculty Publications (Cleveland State University, Cleveland, OH) Paper 3. Available at http://engagedscholarship.csuohio.edu/encee_facpub/3

[25] Quinn GD (2013) Notes on aluminum oxide $\left(\mathrm{Al}_{2} \mathrm{O}_{3}\right)$ strength data. Private communication with Stephen W. Freiman steve.freiman@comcast.net 
[26] NRIM (1994) Data sheets on the elevated temperature properties of high strength steel (class $590 \mathrm{MPa}$ ) plates for pressure vessels. NRIM Creep Data Sheet, Second Revision (No. 25B), 30 September 1994 (National Research Institute for Metals, Tokyo, Japan). https://doi.org/10.11503/nims.1029

[27] Margetson J, Cooper NR (1984) Brittle material design using three parameter Weibull distributions. Probabilistic Methods in the Mechanics of Solids and Structures, eds Eggwertz S, Lind NC (Springer-Verlag, Berlin) pp 253-262.

https://doi.org/10.1007/978-3-642-82419-7

\begin{abstract}
About the authors: Jeffrey T. Fong is a physicist in the Applied and Computational Mathematics Division at NIST. Alan Heckert is a mathematical statistician in the Statistical Engineering Division at NIST. James J. Filliben is a mathematical statistician in the Statistical Engineering Division at NIST. Pedro V. Marcal is president of MPACT, Corp., Oak Park, CA, USA. Stephen W. Freiman is president of Freiman Consulting, Potomac, MD, USA.
\end{abstract}

The National Institute of Standards and Technology is an agency of the U.S. Department of Commerce. 